\title{
Landscape and Regional Impacts of Hurricanes in New England
}

\section{Citation}

Boose, Emery R., Kristen E. Chamberlin, and David R. Foster. 2001. “Landscape and Regional Impacts of Hurricanes in New England." Ecological Monographs 71 (1) (February): 27. doi: $10.2307 / 3100043$.

\section{Published Version}

doi:http:10.2307/3100043

\section{Permanent link}

http://nrs.harvard.edu/urn-3:HUL.InstRepos:29395000

\section{Terms of Use}

This article was downloaded from Harvard University's DASH repository, and is made available under the terms and conditions applicable to Other Posted Material, as set forth at http:// nrs.harvard.edu/urn-3:HUL.InstRepos:dash.current.terms-of-use\#LAA

\section{Share Your Story}

The Harvard community has made this article openly available.

Please share how this access benefits you. Submit a story.

Accessibility 


\title{
LANDSCAPE AND REGIONAL IMPACTS OF HURRICANES IN NEW ENGLAND
}

\author{
Emery R. Boose, Kristen E. Chamberlin, ${ }^{1}$ And David R. Foster
}

Harvard Forest, Harvard University, Petersham, Massachusetts 01366 USA

\begin{abstract}
Hurricanes are a major factor controlling ecosystem structure, function, and dynamics in many coastal forests, but their ecological role can be understood only by assessing impacts in space and time over a period of centuries. We present a new method for reconstructing hurricane disturbance regimes using a combination of historical research and computer modeling. Historical evidence of wind damage for each hurricane in the selected region is quantified using the Fujita scale to produce regional maps of actual damage. A simple meteorological model (HURRECON), parameterized and tested for selected recent hurricanes, provides regional estimates of wind speed, direction, and damage for each storm. Individual reconstructions are compiled to analyze spatial and temporal patterns of hurricane impacts. Long-term effects of topography on a landscape scale are then simulated with a simple topographic exposure model (EXPOS).

We applied this method to the region of New England, USA, examining hurricanes since European settlement in 1620. Results showed strong regional gradients in hurricane frequency and intensity from southeast to northwest: mean return intervals for F0 damage on the Fujita scale (loss of leaves and branches) ranged from 5 to $85 \mathrm{yr}$, mean return intervals for F1 damage (scattered blowdowns, small gaps) ranged from 10 to $>200 \mathrm{yr}$, and mean return intervals for F2 damage (extensive blowdowns, large gaps) ranged from 85 to $>380$ yr. On a landscape scale, mean return intervals for F2 damage in the town of Petersham, Massachusetts, ranged from $125 \mathrm{yr}$ across most sites to $>380 \mathrm{yr}$ on scattered lee slopes. Actual forest damage was strongly dependent on land use and natural disturbance history. Annual and decadal timing of hurricanes varied widely. There was no clear centuryscale trend in the number of major hurricanes.

The historical-modeling approach is applicable to any region with good historical records and will enable ecologists and land managers to incorporate insights on hurricane disturbance regimes into the interpretation and conservation of forests at landscape to regional scales.

Key words: Fujita scale; historical record; hurricane; landscape patterns; modeling; natural disturbance; New England (USA); regional patterns; temperate forests; topographic exposure; wind damage.
\end{abstract}

\section{INTRODUCTION}

Many coastal regions are subject to severe impacts by hurricanes and typhoons, including wind damage to forests, scouring and flooding of river channels, and salt water inundation along shorelines (Dunn and Miller 1964, Simpson and Riehl 1981, Diaz and Pulwarty 1997). Tropical storms can generate intensive forest disturbance extending inland many hundreds of kilometers. Effects can be highly variable, depending on meteorological, topographical, and biological factors, and the intensity of damage can range from leaf stripping and branch break to individual tree gaps to extensive blowdowns (Foster and Boose 1992, Boose et al. 1994). Because of the longevity of trees, the range of biological and physical damage, and the lags and legacies inherent in ecological systems; tropical storms

Manuscript received 22 July 1999; revised 20 December 1999; accepted 6 January 2000; final version received 22 February 2000 .

${ }^{1}$ Present address: P.O. Box 305, Colrain, Massachusetts 01340 USA. may shape ecosystem, landscape, and regional characteristics over very long periods of time (Foster et al. 1998).

An understanding of the history and role of hurricanes is a priority for ecologists seeking to interpret natural ecosystems as well as for conservation biologists and silviculturalists seeking to inform management decisions. Recent management, for example, has focused on adjusting rotation lengths to fit natural storm frequencies and impacts (e.g., Quine 1995, Studholme 1995), designing landscape-level silvicultural approaches to reduce the impacts of future storms (e.g., Metropolitan District Commission 1995), or mimicking some of the effects and temporal patterns of hurricanes in sustainable forestry systems (e.g., Hunter 1993). However, all of these efforts have been based on inferences from a small number of storms over recent decades in limited geographic areas.

There remains a strong need for more information on hurricane frequency, intensity, and size over larger areas and longer time spans, in order to understand 
disturbance regimes that typically include both frequent, low-intensity events and infrequent, intense ones. In theory it would be possible to take an approach similar to that employed in reconstructing fire disturbance regimes in which stand origin and fire history maps are compiled over an extensive area (e.g., Heinselman 1973, Foster 1983, Johnson 1992). However, given the time span, geographic area, and complexity of damage patterns under consideration it is hardly surprising that such attempts have failed to yield complete regional interpretations. Past efforts include: (1) detailed forest stand reconstructions (e.g., Stephens 1955, Henry and Swan 1974), which provide lengthy and accurate records but are severely restricted in spatial coverage; (2) compilations of historical information (e.g., Ludlum 1963), which may be comprehensive geographically but provide little insight into ecosystem impacts; (3) compilations of storm tracks and calculation of geographical frequencies (e.g., Scatena and Larsen 1991), which largely ignore variation in storm intensity or size; (4) extrapolation from single notable events such as the 1938 hurricane in New England (e.g., Metropolitan District Commission 1995), which simplifies the inherent variability among storms; and (5) paleoecological and geomorphological approaches (e.g., Liu and Fearn 1997) that are most successful in coastal areas. Most studies by ecologists have avoided considerations of hurricane meteorology. One important exception is that of D. M. Smith (1946) who used meteorological characteristics of the major historical storms in a single region (New England) to infer the distribution of intense winds and compile a general chronology of storm damage in time and space.

In order to improve on past attempts and to address many of their shortcomings, we developed an approach and tools that combine historical research, wind damage assessment, and meteorological modeling to provide multiple lines of evidence on hurricanes and wind damage over any geographic area and historical timeframe (Boose et al. 1994, Foster and Boose 1995, Boose et al. 1997). The resulting historical-modeling method involves six steps: (1) Identify all historical hurricanes with damaging winds in the selected region. (2) Collect wind damage reports and meteorological observations for each storm. (3) Analyze and compile the damage reports into regional maps of actual damage. (4) Parameterize and test a simple meteorological model (HURRECON) with data from selected recent hurricanes. (5) Use the parameterized model to reconstruct each storm. Finally, (6) compile the results of individual storm reconstructions to study the spatial and temporal patterns of hurricane impacts during the historical period. The long-term effects of topography on a landscape scale can then be examined with a simple topographic exposure model (EXPOS).

In the current project we applied this method to study hurricane impacts in the region of New England, USA, over a period of $378 \mathrm{yr}$ from 1620 to 1997 . The re- sulting gradients of hurricane frequency and intensity across the region matched the general patterns expected from the fact that hurricanes weaken over land or cold ocean water. However the historical-modeling method enabled us to quantify these gradients and to evaluate site and landscape-level impacts at a level of detail and accuracy not previously possible. The HURRECON and EXPOS models and the historical data used in our analysis of New England hurricanes are available on the Harvard Forest web page. ${ }^{2}$

\section{STUdy AREA}

\section{New England}

The six New England states plus adjoining New York City and Long Island form the study region of $\sim 175000 \mathrm{~km}^{2}$. Topographic relief varies from coastal plains to mountains of $1000 \mathrm{~m}$ elevation (maximum $1900 \mathrm{~m}$ ) to the west and north. Differences in elevation, latitude, and distance from the ocean produce significant climatic gradients. For example, mean annual temperatures range from $11^{\circ} \mathrm{C}$ in Bridgeport, Connecticut, to $4^{\circ} \mathrm{C}$ in Caribou, Maine (National Climatic Data Center web page). ${ }^{3}$

The region contains four major vegetation zones, based on dominant tree species (Westveld 1956, Foster and Aber 2001): (1) Northern hardwoods-spruce-fir (northern New England and higher elevations). Hardwoods include beech (Fagus grandifolia), yellow birch (Betula alleghaniensis), sugar maple (Acer saccarum), paper birch (B. papyrifera), and red maple (A. rubrum). Conifers include red spruce (Picea rubens) and balsam fir (Abies balsamea), replaced by hemlock (Tsuga canadensis) and white pine (Pinus strobus) in southern areas and lower elevations. (2) Transition hardwoods (central New England). Northern hardwood species (beech, birches, and maples) overlap with oaks and hickories of the central hardwoods. White pine and hemlock are common conifers. (3) Central hardwoods (southern New England). Hardwoods include red, black, and white oaks (Quercus rubra, Q. velutina, $Q$. alba), and shagbark and bitternut hickories (Carya ovata, C. cordiformis). Common softwoods are white pine and hemlock. (4) Pitch pine-oak (Cape Cod, the islands, and scattered sand plains). Dominant species are pitch pine $(P$. rigida) and scrub oak ( $Q$. ilicifolia).

European settlement began in 1620 in Massachusetts and spread gradually inland. By 1800 most of the region (except northern Maine and the mountains) was settled and cleared for dispersed agriculture, which reached a peak in the mid-1800s. By 1900 populations were concentrated in the larger cities and industrial towns, with widespread farm abandonment and reforestation in surrounding areas (Foster and Aber 2001).

\footnotetext{
${ }^{2}$ URL: $\langle$ http://lternet.edu/hfr $\rangle$

${ }^{3}$ URL: 〈http://www.ncdc.noaa.gov $\rangle$
} 


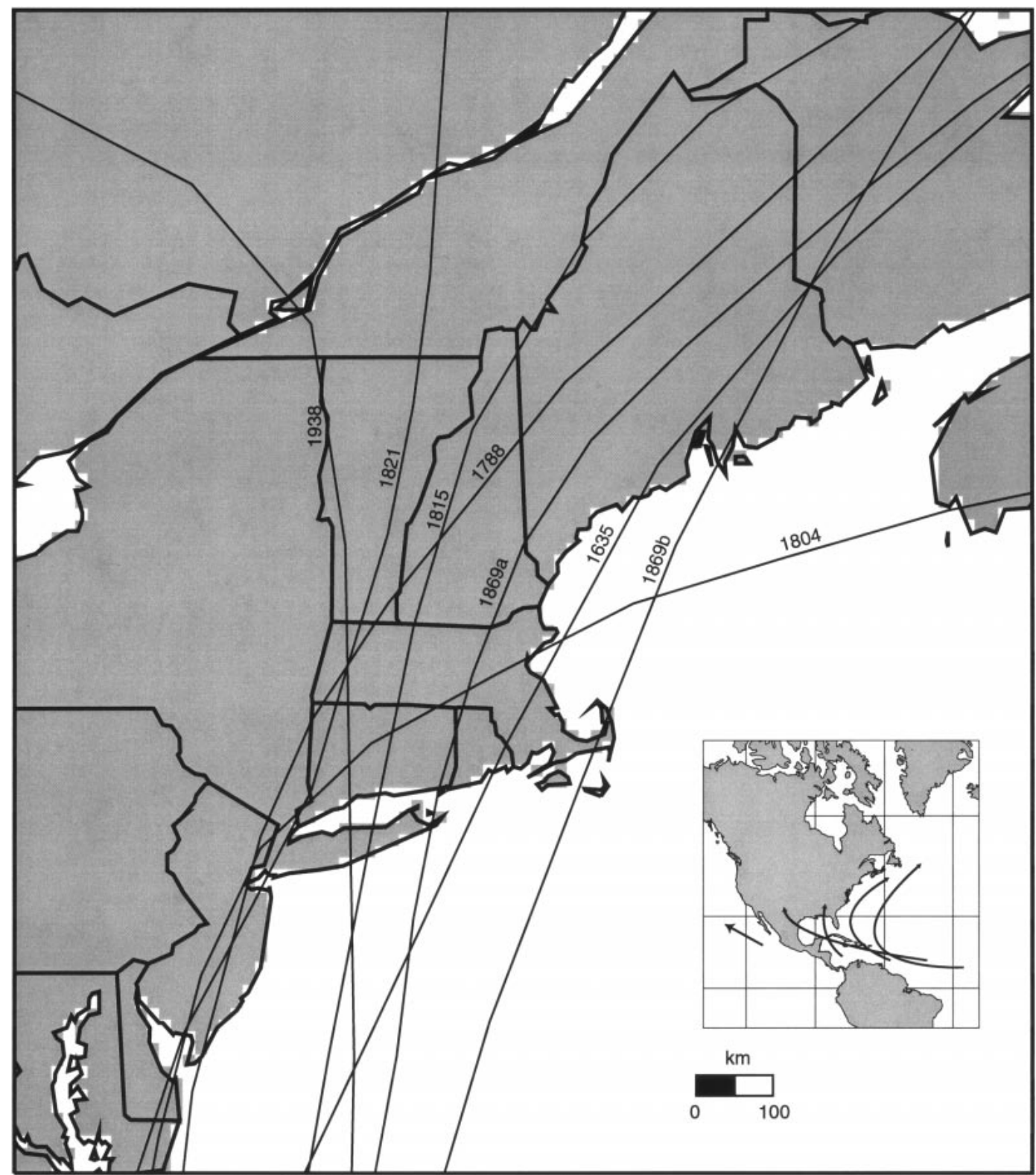

FIG. 1. Tracks of eight hurricanes that caused F3 damage on the Fujita scale (see Table 1) in the study region during the historical period (1620-1997). Inset: common hurricane paths in the North Atlantic (adapted from Dunn and Miller 1964).

\section{Hurricanes in New England}

New England is affected by mature and late-stage Atlantic hurricanes that form at lower latitudes and approach from the south. Most hurricanes weaken by the time they reach New England, though an intensity of category 3 on the Saffir-Simpson scale (sustained wind speeds of $50-58 \mathrm{~m} / \mathrm{s}$ ) is not unusual (Simpson and Riehl 1981). The regional impact of hurricanes is controlled in part by the storm track (Smith 1946). Because hurricanes derive most of their energy from warm ocean water, hurricanes that cross the Atlantic coastline and pass over inland areas to the south and west generally cause little wind damage in New England. Similarly, because the highest surface winds are normally located to the right of the storm track (where the forward motion of the storm and the counterclockwise rotation of wind around the center coincide), storms that pass offshore to the east also tend to cause less wind damage. The greatest impacts result from hurricanes that travel northward over the warm waters of the Gulf Stream and pass directly over New England (Fig. 1). Rapid forward motion helps to offset the effects of weakening as the storms come over land or over the cold waters of the Gulf of Maine. The mete- 
orological structure of the hurricane may be transformed from tropical to extratropical with the influx of cold air, occasionally resulting in short-term intensification (Simpson and Riehl 1981).

\section{MeTHODS}

\section{Historical data}

Damage data.-Primary sources of wind damage data included: (1) For the period 1871-1997, contemporary newspapers, especially The Boston Globe and The New York Times. (2) For the period 1700-1871, contemporary newspapers from Boston, Massachusetts; Concord, New Hampshire; New Bedford, Massachusetts; New York, New York; Northampton, Massachusetts; Portland, Maine; Providence, Rhode Island; and other cities, depending on the area of impact. (3) For the period 1620-1699, personal diaries and town histories (especially at the American Antiquarian Society, Worcester, Massachusetts). Primary sources cited in Ludlum (1963) were consulted wherever possible. Secondary materials included studies of great or recent hurricanes (e.g., Darling 1842, Perley 1891, Tyler 1938, Minsinger 1988, Minsinger and Orloff 1992, 1994). Efforts focused on obtaining a good map of regional damage for each hurricane.

Meteorological data.-The range and quantity of meteorological data have increased dramatically since 1620 as a result of a more widely distributed population, better historical records, and steady improvements in technology (Ludlum 1963, Neumann et al. 1987). Primary sources of meteorological data included: (1) For the period 1871-1997, the HURDAT (Hurricane Data) database maintained by the U.S. National Hurricane Center, which provides location and maximum sustained (1-min) wind speed every $6 \mathrm{~h}$ for Atlantic hurricanes since 1886 , and location every $12 \mathrm{~h}$ for the period 1871-1885. HURDAT data for 1871-1992 were retrieved from the Global Tropical/Extratropical Cyclone Climatic Atlas (NOAA 1994), and for 1993-1997 from the National Hurricane Center web page. ${ }^{4}$ Studies of individual hurricanes in the Monthly Weather Review were consulted. Wind observation data from surface stations throughout New England were obtained from the U.S. National Climatic Data Center for six hurricanes since 1938. (2) For the period 1620-1870, contemporary accounts of each storm from historical records, analyses of each storm by Ludlum (1963), and reconstructed tracks for hurricanes since 1851 by Fernandez-Partagas and Diaz (1995). Though actual measurements of wind speed are not available, early observers often left careful records of wind speed (in qualitative terms) and direction (eight points of the compass), and noted the times of peak wind, wind shift, lulls, and changes in cloud cover and precipitation intensity.

Hurricane selection.-Sixty-seven hurricanes were

${ }^{4}$ URL: 〈http://www.nhc.noaa.gov〉 selected for detailed study, based on the following criteria: (1) For the period 1886-1997, HURDAT was used to identify all tropical storms with sustained winds of hurricane force $(33 \mathrm{~m} / \mathrm{s})$ or greater within $200 \mathrm{~km}$ of the New England coastline (36 hurricanes). (2) For the period 1871-1885, HURDAT was used to identify all tropical storms that approached within $200 \mathrm{~km}$ of the New England coastline. Those storms with historical evidence of major wind damage ( $\mathrm{F} 1$ or higher on the Fujita scale; see next section) were included (1 hurricane). (3) For the period 1620-1870, all hurricanes for which Ludlum (1963) presented evidence of major wind damage $(\mathrm{F} 1+)$ were included (30 hurricanes).

\section{Actual damage}

Fujita scale.-Damage to trees, buildings, and other property was classified using Fujita's $(1971,1987)$ system for assessing wind damage in tornadoes and hurricanes, which is used by the U.S. National Weather Service for tornadoes (Grazulis 1993). Fujita's broad damage classes extend from F0 (minor damage caused by gale or storm force winds) to F5 (extreme damage in the most severe tornadoes). Each F-scale (Fujita scale) class is defined by specified levels of damage to various common objects in the landscape. The system was designed for rapid application in the field and does not require detailed engineering analysis.

For this study, Fujita's original system was modified and extended slightly for better application to the historical materials utilized (Table 1). These changes were based in part on the work of Grazulis (1993) and in part on historical evidence of comparable damage in the hurricanes studied (e.g., town halls in New England tended to suffer damage comparable to churches and barns, in the same location and the same storm). The following changes were most important: (1) One or more trees blown down was classified as F1. F0 was assigned only if the report stated that the tree was weak. Fujita regarded the pushing over of shallow-rooted trees as F0, but in most cases it was impossible to determine the condition of the tree from the historical reports. (2) Part or all of a roof blown off of a wood frame house was classified as F2. Fujita required that the entire roof be removed, but again in most cases it was impossible to determine exactly how much of the roof was gone. (3) Damage to wood frame houses was assigned F3 only if at least three houses in the same town were completely blown down; this restriction was added to increase the likelihood that at least one of the three houses was well built and in good condition. (4) F3 was assigned to forest damage only in two extreme cases (N1635 and N1869b; see Table 4 for hurricane codes) where it was supported by comparable damage to houses. (5) Damage to unfinished buildings was not classified except in a few cases where little other information was available; in such cases the normal Fujita rating was reduced by one class. (6) In 
TABLE 1. The Fujita scale of wind damage, with minor modifications for use in this study.

\begin{tabular}{|c|c|c|c|c|}
\hline Fujita rating & F0 damage & F1 damage & F2 damage & F3 damage \\
\hline $\begin{array}{l}\text { Sustained wind speed } \\
(\mathrm{m} / \mathrm{s})\end{array}$ & $18-25$ & $26-35$ & $36-47$ & $48-62$ \\
\hline Trees & $\begin{array}{l}\text { Leaves and fruit off, } \\
\text { branches broken, } \\
\text { trees damaged }\end{array}$ & Trees blown down & Extensive blowdowns & $\begin{array}{l}\text { Most trees } \\
\text { down }\end{array}$ \\
\hline Crops & $\begin{array}{l}\text { Damaged or blown } \\
\text { down }\end{array}$ & & & \\
\hline Buildings (unspecified) & Minor damage & Unroofed or damaged & $\begin{array}{l}\text { Blown down or } \\
\text { destroyed }\end{array}$ & \\
\hline Masonry buildings & Minor damage & $\begin{array}{l}\text { Roof peeled, windows } \\
\text { broken, chimneys } \\
\text { down }\end{array}$ & Unroofed & $\begin{array}{l}\text { Blown down } \\
\text { or destroyed }\end{array}$ \\
\hline Wood houses & Minor damage & $\begin{array}{l}\text { Roof peeled, windows } \\
\text { broken, chimneys } \\
\text { down }\end{array}$ & Unroofed or destroyed & $\begin{array}{l}3+\text { Blown } \\
\text { down }\end{array}$ \\
\hline $\begin{array}{l}\text { Barns, cottages, church- } \\
\text { es, town halls }\end{array}$ & Minor damage & $\begin{array}{l}\text { Unroofed, steeple } \\
\text { blown down }\end{array}$ & $\begin{array}{l}\text { Blown down or } \\
\text { destroyed }\end{array}$ & \\
\hline $\begin{array}{l}\text { Shacks, sheds, outbuild- } \\
\text { ings, warehouses }\end{array}$ & Minor damage & $\begin{array}{l}\text { Unroofed, blown down, } \\
\text { or destroyed }\end{array}$ & & \\
\hline Brick or block walls & No damage & Blown down & & \\
\hline Utility poles & Wires down & $\begin{array}{l}\text { Poles damaged or } \\
\text { blown down }\end{array}$ & & \\
\hline Signs, fences & Some damage & Blown down & & \\
\hline Autos & No damage & $\begin{array}{l}\text { Moving autos pushed } \\
\text { off road }\end{array}$ & $\begin{array}{l}\text { Stationary autos moved } \\
\text { or pushed over }\end{array}$ & \\
\hline Trains & No damage & Pushed along tracks & Boxcars pushed over & \\
\hline Small airplanes & Minor damage & Destroyed & & \\
\hline Missiles & None & None & Light objects & \\
\hline
\end{tabular}

Note: Corresponding sustained wind speed values are derived from Fujita's equations (1971), assuming a wind gust factor of 1.5 over land.

general, damage to other objects (such as bridges) not considered by Fujita or Grazulis was not classified.

The Fujita scale provided a means to quantify the level of wind damage caused by historical hurricanes and a link to the meteorological modeling described below, through the range of wind speeds proposed by Fujita for each damage class (1971; Table 1). Though some engineers have suggested that Fujita's wind speeds may be too high, especially for F3-F5 damage (e.g., Twisdale
1978, Liu 1993), and much work is still needed to understand the forces generated on buildings in hurricane winds (Powell et al. 1994), Fujita's values were found to work well for the lower damage classes (F0-F3) treated in this study.

Database and map compilation.-Reports of wind damage were collected and indexed by town to create a database for each hurricane, and each report that contained sufficient information was assigned an F-scale val-

TABLE 2. Sample record from the database of historical reports for the Great Colonial Hurricane (N1635).

\begin{tabular}{|c|c|}
\hline Parameter & Record \\
\hline Hurricane & N1635 \\
\hline Location & Plymouth, Massachusetts \\
\hline Source & William Bradford, Of Plymouth Plantation 1620-1647 \\
\hline $\begin{array}{c}\text { Meteorological } \\
\text { observations }\end{array}$ & $\begin{array}{l}\text { "This year... was such a mighty storm of wind and rain as none living in these parts, either English } \\
\text { or Indians, ever saw. . . It began in the morning a little before day, and grew not by degrees but } \\
\text { came with violence in the beginning, to the great amazement of many. . . It began in the southeast } \\
\text { and parted toward the south and east, and veered sundry ways, but the greatest force of it here was } \\
\text { from the former quarters. It continued not (in the extremity) above five or six hours but the violence } \\
\text { began to abate.". }\end{array}$ \\
\hline Storm surge & $\begin{array}{l}\text { "Divers vessels were lost at sea and many more in extreme danger. It caused the sea to swell to the } \\
\text { south wind of this place above } 20 \text { foot right up and down, and made many of the Indians to climb } \\
\text { into trees for their safety. ... And if it had continued long without the shifting of the wind, it is like } \\
\text { it would have drowned some part of the country." }\end{array}$ \\
\hline Damage & $\begin{array}{l}\text { "It blew down sundry houses and uncovered others. It took off the boarded roof of a house which } \\
\text { belonged to this Plantation at Manomet, and floated it to another place, the posts still standing in the } \\
\text { ground. . . . It blew down many hundred thousands of trees, turning up the stronger by the roots and } \\
\text { breaking the higher pine trees off in the middle. And the tall young oaks and walnut trees of good } \\
\text { bigness were wound like a withe, very strange and fearful to behold. . . The signs and marks of it } \\
\text { will remain this hundred years in these parts where it was sorest." }\end{array}$ \\
\hline Fujita rating & ( \\
\hline
\end{tabular}


TABLE 3. Adjustments to maximum sustained wind speed $\left(V_{\mathrm{m}}\right)$ values in the HURDAT database for nine hurricanes.

\begin{tabular}{|c|c|c|c|c|c|}
\hline Hurricane & Month & Day & Hour & $\begin{array}{c}\text { HUR- } \\
\text { DAT } \\
V_{\mathrm{m}}(\mathrm{m} / \mathrm{s})\end{array}$ & $\begin{array}{l}\text { Adjusted } \\
V_{\mathrm{m}}(\mathrm{m} / \mathrm{s})\end{array}$ \\
\hline \multirow[t]{4}{*}{ N1893b } & 8 & 24 & 1800 & 39 & 36 \\
\hline & 8 & 25 & 0000 & 36 & 31 \\
\hline & 8 & 25 & 0600 & 33 & 26 \\
\hline & 8 & 25 & 1200 & 31 & 26 \\
\hline \multirow[t]{2}{*}{ N1896 } & 9 & 11 & 1200 & 41 & 36 \\
\hline & 9 & 11 & 1800 & 39 & 31 \\
\hline \multirow[t]{4}{*}{ N1916 } & 7 & 21 & 0000 & 44 & 41 \\
\hline & 7 & 21 & 0600 & 41 & 36 \\
\hline & 7 & 21 & 1200 & 39 & 31 \\
\hline & 7 & 21 & 1800 & 33 & 28 \\
\hline \multirow{2}{*}{ N1924 } & 8 & 26 & 1200 & 51 & 54 \\
\hline & 8 & 26 & 1800 & 46 & 54 \\
\hline \multirow[t]{6}{*}{ N1938 } & 9 & 21 & 1200 & 51 & 57 \\
\hline & 9 & 21 & 1800 & 44 & 57 \\
\hline & 9 & 21 & 2000 & & 57 \\
\hline & 9 & 22 & 0000 & 36 & 46 \\
\hline & 9 & 22 & 0600 & 23 & 31 \\
\hline & 9 & 22 & 0900 & & 23 \\
\hline \multirow[t]{4}{*}{ N1944 } & 9 & 14 & 1800 & 44 & 46 \\
\hline & 9 & 15 & 0000 & 39 & 46 \\
\hline & 9 & 15 & 0600 & 33 & 44 \\
\hline & 9 & 15 & 1200 & 18 & 28 \\
\hline \multirow[t]{2}{*}{ N1954b } & 9 & 11 & 1200 & 46 & 51 \\
\hline & 9 & 11 & 1800 & 41 & 49 \\
\hline \multirow[t]{4}{*}{ N1961 } & 9 & 21 & 0000 & 59 & 57 \\
\hline & 9 & 21 & 0600 & 57 & 49 \\
\hline & 9 & 21 & 1200 & 57 & 41 \\
\hline & 9 & 21 & 1800 & 54 & 36 \\
\hline N1991 & 8 & 19 & 1800 & 44 & 46 \\
\hline
\end{tabular}

Note: Adjusted values were used in reconstructions with the HURRECON model.

ue based on the highest level of damage reported (Table 2). Care was taken to exclude coastal damage caused by the storm surge and valley damage caused by river flooding. Maps of actual wind damage were then created for each hurricane, using the maximum F-scale value assigned for each town. For mapping purposes, references to New York City and Martha's Vineyard were assumed to refer to all five boroughs and six towns, respectively; though individual boroughs or towns were treated separately if referenced separately in the reports. However, in the analysis of the maps, New York City and Martha's Vineyard were each treated as a single town. Reports from larger areas (e.g., entire counties or states) were assigned F-scale values but were not used in the creation of the damage maps. Map resolution was $2.5 \mathrm{~km}$.

\section{Meteorological reconstructions}

Hurrecon model.-A simple meteorological model (HURRECON; Boose et al. 1994), based on published empirical studies of many hurricanes, was used to reconstruct each storm (Fig. 2). The model estimates surface wind speed and direction based on the track, size, and intensity of a hurricane and the surface type (land or water). Recent improvements in the model (Boose et al. 1997) include: (1) an estimate of Fujita-scale wind damage from peak wind speed, using the correlation between maximum 1/4-mile wind velocity (i.e., maximum wind velocity sustained over a quarter mile distance) and wind damage proposed by Fujita (1971); and (2) the original wind profile equations were replaced with Holland's equation for the cyclostrophic wind (Holland 1980: Eq. 5), which gives a more rounded wind profile and renders accurate determination of the radius of maximum winds less critical.

Model equations are given below. Wind velocity and direction are measured relative to the Earth's surface, and angles are measured in degrees. Parameter values used in this study are given in parentheses. The sustained wind velocity $\left(V_{\mathrm{s}}\right)$ at any point $P$ in the northern hemisphere is estimated as

$$
\begin{aligned}
V_{\mathrm{s}}= & F\left[V_{\mathrm{m}}-S(1-\sin T) V_{\mathrm{h}} / 2\right] \\
& \times\left[\left(R_{\mathrm{m}} / R\right)^{B} \exp \left(1-\left(R_{\mathrm{m}} / R\right)^{B}\right)\right]^{1 / 2}
\end{aligned}
$$
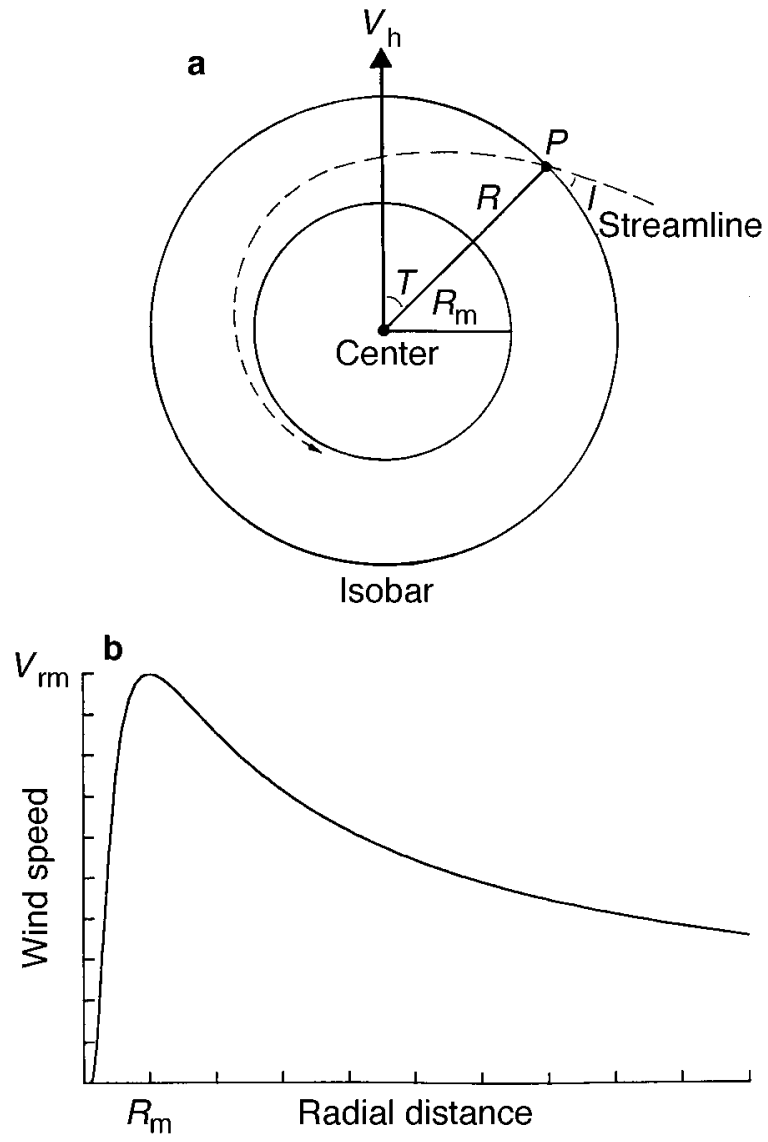

FIG. 2. HURRECON model. (a) At the surface, air is drawn into the hurricane along spiral streamlines that cross the nearly circular isobars at inflow angle $I$. The estimated wind direction at point $P$ is a function of $I$ and the relative positions of $P$ and the storm center. (b) The estimated wind speed along a radial line outward from the storm center is a function of the radius of maximum winds $\left(R_{\mathrm{m}}\right)$, the wind speed at that radius $\left(V_{\mathrm{rm}}\right)$, and the scaling parameter $B$ which controls the shape of the curve. $V_{\mathrm{rm}}$ varies as a function of the forward velocity of the storm $\left(V_{\mathrm{h}}\right)$ and the angle $T$, and it reaches a maximum $\left(V_{\mathrm{m}}\right)$ at $T=90^{\circ}$. 
(a) Actual Damage

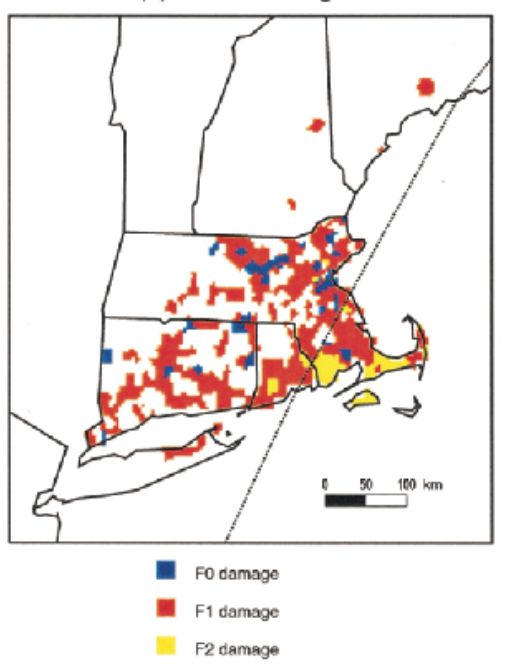

(b) Reconstructed Damage

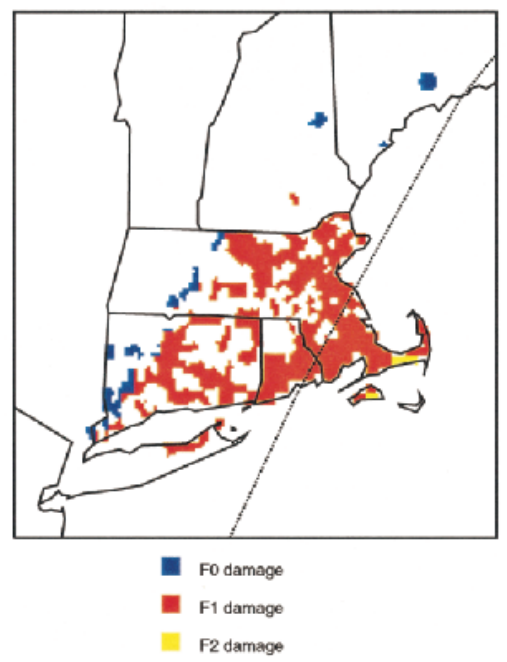

(c) Difference

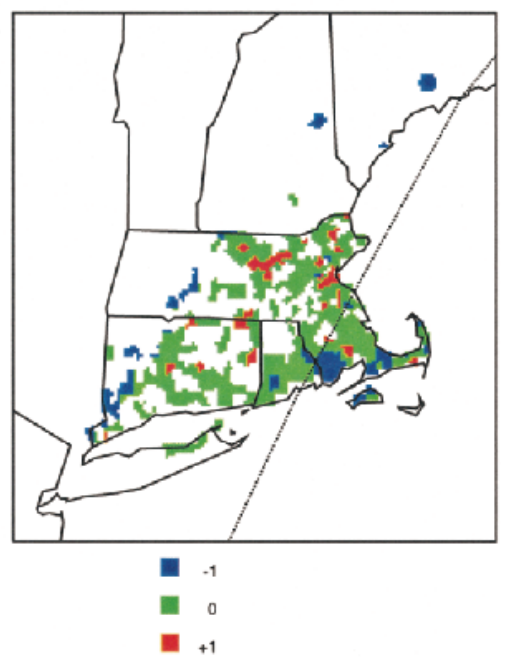

FIG. 3. Comparison of actual and reconstructed wind damage on the Fujita scale for Hurricane Bob (N1991): (a) Actual damage by town; (b) Reconstructed damage for the same towns at 10-km resolution using the HURRECON model; (c) Difference map showing reconstructed damage minus actual damage.

where $F$ is a scaling parameter for effects of friction (water $=1.0$, land $=0.8), V_{\mathrm{m}}$ is the maximum sustained wind velocity over water anywhere in the hurricane, $S$ is a scaling parameter for asymmetry due to forward motion of the storm (1.0), $T$ is the clockwise angle between forward path of the hurricane and a radial line from the hurricane center to point $P, V_{\mathrm{h}}$ is the forward velocity of the hurricane, $R_{\mathrm{m}}$ is the radius of maximum winds $(50-100 \mathrm{~km}), R$ is the radial distance from the hurricane center to point $P$, and $B$ is a scaling parameter controlling shape of wind profile curve (1.3). The peak wind gust velocity $\left(V_{\mathrm{g}}\right)$ at point $P$ is estimated from $V_{\mathrm{s}}$ as follows:

$$
V_{\mathrm{g}}=G V_{\mathrm{s}}
$$

where $G$ is a gust factor (water $=1.2$, land $=1.5$ ). The maximum $1 / 4$ mile wind velocity $\left(V_{\mathrm{f}}\right)$ is estimated from $V_{\mathrm{s}}$ and $G$ using Fujita's method (Fujita 1971: Eq. 12). Wind direction $(D)$ at point $P$ is estimated as

$$
D=A_{\mathrm{z}}-90-I
$$

where $A_{\mathrm{z}}$ is the azimuth from point $P$ to the hurricane center and $I$ is the cross isobar inflow angle (water $=$ $20^{\circ}$, land $=40^{\circ}$ ). In the southern hemisphere, where the wind circulation is clockwise around the center, $T$ is the counterclockwise angle between forward path of hurricane and a radial line from hurricane center to point $P$, and $D=A_{\mathrm{z}}+90+I$.

Parameterization and validation.-The original HURRECON model was tested in detailed studies of the 1938 New England Hurricane and Hurricane Hugo in Puerto Rico (Boose et al. 1994). For this study, the revised model was parameterized and tested as follows: (1) Parameters were assigned from the literature and adjusted as necessary in detailed studies of the six ma- jor hurricanes since 1938 (N1938, N1944, N1954a, N1960, N1985, and N1991). For each of these storms, model estimates were compared to actual wind and damage observations. The goal was to find parameters or a range of parameters that worked well for all six storms. (2) The model thus parameterized was tested by comparing actual and reconstructed damage for the remaining 30 hurricanes since 1886, where damage data were independent of the (input) meteorological data. (3) The model was then applied to the 31 hurricanes before 1886 , where the damage data were used to help determine the (input) storm track and/or maximum wind speed.

Parameter values for $F, G$, and $I$ were adopted directly from published sources (Dunn and Miller 1964, Fujita 1971, Simpson and Riehl 1981, Powell 1982, Powell 1987); $F$ and $G$ were chosen so that peak gust speeds are the same over water and land. The value $S$ $=2.0$ reported in the literature (i.e., peak wind speed on right side minus peak wind speed on left side $=$ $2 V_{\mathrm{h}}$ ) was found to consistently underestimate wind speed and damage on the left side of the storm; better results were obtained with $S=1.0$. The width of the modeled storm (for a given value of $V_{\mathrm{m}}$ ) is controlled by the parameters $B$ and $R_{\mathrm{m}}$. A low value for $B(1.3)$ was selected to match the relatively flat wind profiles in New England hurricanes. Direct measurements of the radius of maximum winds $\left(R_{\mathrm{m}}\right)$ were unavailable for all but the most recent hurricanes (H. Willoughby, personal communication). For this reason, and to test model sensitivity to this critical parameter, each storm was separately modeled for three values of $R_{\mathrm{m}}(50,75$, and $100 \mathrm{~km}$ ), and the value of $R_{\mathrm{m}}$ that produced the best agreement between actual and reconstructed regional damage was selected for the final results. Input 
variables for each model run included location of the storm center and maximum sustained wind velocity $\left(V_{\mathrm{m}}\right)$ at regular (usually $6 \mathrm{~h}$ ) intervals.

HURRECON provides estimates for individual sites (as tables) and for entire regions (as GIS maps in Idrisi format; Eastman 1997). Model runs for individual sites were made using a time step of $5 \mathrm{~min}$; output variables included peak wind speed and direction and maximum F-scale damage for each storm. The cover type for individual sites was assumed to be land. Regional estimates were made at $10-\mathrm{km}$ resolution using a time step equal to the minimum time required for each hurricane to traverse one $10 \times 10-\mathrm{km}$ grid cell within the regional study window $\left(38^{\circ}-48^{\circ} \mathrm{N}\right.$ latitude, $65^{\circ}-77^{\circ} \mathrm{W}$ longitude). Output maps included peak wind speed and maximum F-scale damage across the region for each storm.

Model reconstructions were tested by comparing actual and reconstructed F-scale wind damage on a regional scale (Fig. 3). Such comparisons were quantified by creating and analyzing a difference map (reconstructed damage minus actual damage) for each storm. The difference maps provided a measure of the overall accuracy of each reconstruction as well as the spatial pattern of agreement (e.g., reconstructed values might be too high or too low on one side of the track, or along the fringes of the storm).

Reconstructed and observed wind speeds at surface stations were also compared for the six major hurricanes since 1938. However, a detailed study of observed wind speeds, though desirable, was beyond the scope of this project. Accurate comparisons require careful correction of the observed wind speed for various factors including height of the anemometer, surface roughness over the approaching wind trajectory, and duration of measurement (Powell et al. 1994), information that was difficult or impossible to obtain in many cases. In addition, peak wind speeds were often missed in all but the most recent storms because observations were only made at fixed, infrequent intervals.

Hurricanes 1871-1997.-The meteorological reconstructions of hurricanes from 1871 to 1997 were based on the HURDAT database. Though widely used, HURDAT has known deficiencies (including both systematic and random errors) and is currently under revision by NOAA (Neumann and McAdie 1997). In most cases there was good agreement between observed and reconstructed F-scale wind damage. However for eight hurricanes there were significant discrepancies which were interpreted as stemming from problems with the NOAA data and resolved by making conservative adjustments to the maximum sustained wind speed $\left(V_{\mathrm{m}}\right)$ values in HURDAT (Table 3 ; these values were reported to NOAA). $V_{\mathrm{m}}$ was also increased slightly at one location for N1991, following the reconstruction by Houston and Powell (1993). Finally, the track for N1878 was moved eastward to improve agreement be- tween actual and reconstructed damage, and $V_{\mathrm{m}}$ values assigned according to the procedures described in the next section for storms before 1871 .

Hurricanes 1620-1870.-The meteorological reconstructions of hurricanes from 1620 to 1870 were based on contemporary accounts and published studies. The track of each storm through the New England region was plotted using the map of actual damage and reports of observed peak wind direction, wind shift, and/or passage of the hurricane eye. These data were judged sufficient (for the purposes of this study) to locate tracks for even the earliest hurricanes. Positions were fixed at 2- to 12-h intervals, depending on the forward motion of the storm and the curvature of the track. Tracks were checked against the analyses of Ludlum (1963) and (for storms since 1851) tracks published by Fernandez-Partagas and Diaz (1995). Maximum sustained wind speeds $\left(V_{\mathrm{m}}\right)$ were determined by the level of actual wind damage and through comparisons with wind speeds and damage for 20th century hurricanes. The observed storm surge was also considered as evidence of hurricane intensity at landfall. In general, $V_{\mathrm{m}}$ at landfall was assigned as follows: scattered F3 and extensive inland $\mathrm{F} 2$ damage $=57 \mathrm{~m} / \mathrm{s}(110 \mathrm{knots})$, scattered F3 damage and some inland F2 damage = $49-51 \mathrm{~m} / \mathrm{s}$ (95-100 knots), scattered (mostly coastal) $\mathrm{F} 2$ damage $=46 \mathrm{~m} / \mathrm{s}$ (90 knots), and $\mathrm{F} 1$ and $\mathrm{F} 0$ damage $=41-44 \mathrm{~m} / \mathrm{s}$ (80-85 knots). Hurricanes were assumed to weaken as they passed over or near New England, except for two hurricanes (N1804 and N1869b) where there was evidence of significant and anomalous strengthening (perhaps intensification as the storms became extratropical) in the vicinity of New England.

Compilations.-At the regional scale, maps of reconstructed F-scale damage for each hurricane were compiled to generate maps showing the number of storms at a given minimum intensity (F0, F1, or F2) as well as the maximum F-scale intensity for each 10 $\times 10-\mathrm{km}$ cell. Each frequency map was divided by hand into 4-6 regions, and a mean return time was calculated for each region (rounded to the nearest $5 \mathrm{yr}$ ) based on the mean number of storms and the observation period. Data were analyzed for three observation periods (1) the entire historical period (1620-1997), (2) an intermediate period characterized by improvements in meteorological records and newspaper coverage (18001997), and (3) the modern period beginning with the establishment of the U.S. Signal Corps storm warning system and covered by HURDAT (1871-1997).

For two sites within the regional hurricane gradient (Petersham, Massachusetts, and Providence, Rhode Island), model reconstructions were collated to create (1) timelines of reconstructed F-scale damage as a function of time and (2) plots of reconstructed F-scale damage as a function of reconstructed peak wind direction. Landscape-level impacts in Petersham were explored with the EXPOS model (Boose et al. 1994) and an elevation map at $60-\mathrm{m}$ resolution (digitized from 1: 
TABLE 4. Dates and actual damage by town for the 67 hurricanes investigated in this study.

\begin{tabular}{|c|c|c|c|c|c|c|c|c|c|c|c|c|}
\hline Hurricane & No. & Date & Name & Sources & Rpts & Towns & $\mathrm{F}-$ & F0 & $\mathrm{F} 1$ & $\mathrm{~F} 2$ & F3 & Fmax \\
\hline N1635 & & $25 \mathrm{Aug}$ & & 5 & 18 & 2 & & & & 1 & 1 & F3 \\
\hline N1638a & & $13-14$ Aug & & 1 & 2 & 1 & & & 1 & & & $\mathrm{~F} 1$ \\
\hline N1638b & & $4-5$ Oct & & 2 & 2 & 2 & & 1 & & 1 & & $\mathrm{~F} 2$ \\
\hline N1646 & & $14-15$ Nov & & 2 & 2 & 1 & & & & 1 & & $\mathrm{~F} 2$ \\
\hline N1675 & & $7 \mathrm{Sep}$ & & 2 & 6 & 3 & & 1 & 2 & & & F1 \\
\hline N1683 & & 23 Aug & & 1 & 4 & 1 & & & 1 & & & $\mathrm{~F} 1$ \\
\hline N1698 & & $10 \mathrm{Oct}$ & & 1 & 1 & 1 & & & & 1 & & F2 \\
\hline N1716 & & $24-25$ Oct & & 3 & 10 & 1 & & & 1 & & & F1 \\
\hline N1727 & & $27 \mathrm{Sep}$ & & 4 & 11 & 6 & & & 3 & 3 & & $\mathrm{~F} 2$ \\
\hline N1761 & & $23-24$ Oct & & 4 & 21 & 7 & & 1 & 2 & 4 & & $\mathrm{~F} 2$ \\
\hline N1769 & & $8 \mathrm{Sep}$ & & 7 & 20 & 3 & & & 2 & 1 & & $\mathrm{~F} 2$ \\
\hline N1770 & & $20-21$ Oct & & 9 & 31 & 4 & & & 1 & 3 & & $\mathrm{~F} 2$ \\
\hline N1785 & & $24-25 \mathrm{Sep}$ & & 8 & 11 & 1 & & & & 1 & & F2 \\
\hline N1788 & & 19 Aug & & 16 & 60 & 25 & & 1 & 7 & 16 & 1 & F3 \\
\hline N1804 & & $9 \mathrm{Oct}$ & & 16 & 66 & 20 & & 1 & 9 & 9 & 1 & F3 \\
\hline N1806 & & 23-24 Aug & & 3 & 8 & 3 & & 1 & 2 & & & $\mathrm{~F} 1$ \\
\hline N1815 & & $23 \mathrm{Sep}$ & & 55 & 365 & 92 & 1 & 4 & 29 & 52 & 6 & F3 \\
\hline N1821 & & 3-4 Sep & & 12 & 92 & 32 & & 8 & 8 & 13 & 3 & F3 \\
\hline N1825 & & 4-5 Jun & & 6 & 8 & 1 & & & 1 & & & $\mathrm{~F} 1$ \\
\hline N1830 & & 17-18 Aug & & 5 & 11 & 3 & & & 1 & 2 & & F2 \\
\hline N1839 & & $30-31$ Aug & & 2 & 10 & 3 & & 2 & 1 & & & F1 \\
\hline N1841 & & $3-4$ Oct & & 5 & 41 & 9 & 1 & 2 & 4 & 2 & & $\mathrm{~F} 2$ \\
\hline N1846 & & 13-14 Oct & & 2 & 25 & 15 & & & 7 & 8 & & $\mathrm{~F} 2$ \\
\hline N1849 & & $6-7$ Oct & & 3 & 15 & 4 & & 1 & 1 & 2 & & $\mathrm{~F} 2$ \\
\hline N1850 & & $19 \mathrm{Jul}$ & & 5 & 27 & 2 & & 1 & & 1 & & $\mathrm{~F} 2$ \\
\hline N1854 & 2 & $10-11 \mathrm{Sep}$ & & 5 & 18 & 1 & & & 1 & & & $\mathrm{~F} 1$ \\
\hline N1858 & 3 & $16 \mathrm{Sep}$ & & 5 & 18 & 5 & & 2 & 3 & & & F1 \\
\hline N1861 & 8 & 2-3 Nov & & 1 & 6 & 1 & & & 1 & & & $\mathrm{~F} 1$ \\
\hline N1869a & 6 & 8 Sep & & 7 & 185 & 87 & 1 & 6 & 25 & 51 & 4 & F3 \\
\hline N1869b & 10 & 4 Oct & & 1 & 20 & 3 & & & & 1 & 2 & F3 \\
\hline N1878 & 9 & $23-24$ Oct & & 2 & 6 & 2 & & & 1 & 1 & & $\mathrm{~F} 2$ \\
\hline N1888 & 9 & 27-28 Nov & & 1 & 11 & 1 & & & 1 & & & F1 \\
\hline N1891 & 9 & $13-14$ Oct & & 1 & 1 & n.r. & & & & & & \\
\hline N1893a & 1 & 18 Jun & & 1 & 1 & n.r. & & & & & & \\
\hline N1893b & 4 & 24 Aug & & 1 & 10 & 2 & & 1 & & 1 & & F2 \\
\hline N1893c & 6 & 29 Aug & & 1 & 12 & 4 & & & 3 & 1 & & $\mathrm{~F} 2$ \\
\hline N1896 & 2 & $10-11 \mathrm{Sep}$ & & 1 & 4 & 2 & & 2 & & & & F0 \\
\hline N1903 & 4 & $16 \mathrm{Sep}$ & & 1 & 7 & 2 & & & 1 & 1 & & $\mathrm{~F} 2$ \\
\hline N1904 & 2 & $15 \mathrm{Sep}$ & & 2 & 2 & n.r. & & & & & & \\
\hline N1908 & 2 & 1-2 Aug & & 1 & 1 & n.r. & & & & & & \\
\hline N1916 & 2 & $21 \mathrm{Jul}$ & & 1 & 1 & n.r. & & & & & & \\
\hline N1924 & 2 & 26 Aug & & 1 & 33 & 27 & & 2 & 23 & 2 & & F2 \\
\hline N1927 & 1 & 24 Aug & & 1 & 7 & 2 & & 2 & & & & F0 \\
\hline N1933 & 13 & $17-18 \mathrm{Sep}$ & & 1 & 13 & 7 & & 7 & & & & F0 \\
\hline N1934 & 6 & $8-9$ Sep & & 1 & 5 & 1 & & & 1 & & & $\mathrm{~F} 1$ \\
\hline N1936a & 13 & $19 \mathrm{Sep}$ & & 1 & 13 & 7 & 1 & 2 & 4 & & & $\mathrm{~F} 1$ \\
\hline N1936b & 15 & $24-25 \mathrm{Sep}$ & & 1 & 1 & n.r. & & & & & & \\
\hline N1938 & 4 & $21 \mathrm{Sep}$ & & 3 & 382 & 126 & & 3 & 74 & 48 & 1 & F3 \\
\hline N1940 & 4 & $2 \mathrm{Sep}$ & & 1 & 3 & 2 & & 1 & 1 & & & F1 \\
\hline N1944 & 7 & $15 \mathrm{Sep}$ & & 7 & 149 & 51 & & & 40 & 11 & & $\mathrm{~F} 2$ \\
\hline N1950a & 1 & $20-21$ Aug & Able & 1 & 1 & n.r. & & & & & & \\
\hline N1950b & 4 & $11-12 \mathrm{Sep}$ & Dog & 1 & 6 & 1 & & & 1 & & & $\mathrm{~F} 1$ \\
\hline N1953a & 2 & 15 Aug & Barbara & 1 & 8 & 1 & & & 1 & & & $\mathrm{~F} 1$ \\
\hline N1953b & 3 & $7 \mathrm{Sep}$ & Carol & 2 & 4 & n.r. & & & & & & \\
\hline N1954a & 3 & 31 Aug & Carol & 6 & 157 & 83 & & 3 & 68 & 12 & & $\mathrm{~F} 2$ \\
\hline N1954b & 5 & $11 \mathrm{Sep}$ & Edna & 2 & 48 & 16 & & & 14 & 2 & & F2 \\
\hline N1958 & 4 & 29 Aug & Daisy & 2 & 3 & n.d. & & & & & & \\
\hline N1960 & 5 & $12-13 \mathrm{Sep}$ & Donna & 4 & 112 & 42 & & 4 & 37 & 1 & & $\mathrm{~F} 2$ \\
\hline N1961 & 5 & $21 \mathrm{Sep}$ & Esther & 1 & 7 & 6 & & 6 & & & & F0 \\
\hline N1962a & 1 & 29 Aug & Alma & 1 & 1 & n.r. & & & & & & \\
\hline N1962b & 4 & $7 \mathrm{Oct}$ & Daisy & 1 & 4 & 1 & & & 1 & & & F1 \\
\hline N1963 & 8 & 29 Oct & Ginny & 1 & 4 & 2 & 1 & & 1 & & & F1 \\
\hline N1969 & 7 & $9-10 \mathrm{Sep}$ & Gerda & 2 & 9 & 1 & & 1 & & & & F0 \\
\hline N1976 & 3 & 10 Aug & Belle & 2 & 21 & 9 & & 3 & 6 & & & F1 \\
\hline N1985 & 7 & $27 \mathrm{Sep}$ & Gloria & 6 & 193 & 99 & & 12 & 78 & 9 & & $\mathrm{~F} 2$ \\
\hline N1991 & 2 & 19 Aug & Bob & 1 & 348 & 293 & & 31 & 239 & 23 & & $\mathrm{~F} 2$ \\
\hline N1996 & 5 & $2 \mathrm{Sep}$ & Edouard & 1 & 8 & 6 & & 4 & 2 & & & $\mathrm{~F} 1$ \\
\hline Totals & & & & 263 & 2710 & 1135 & 5 & 116 & 710 & 285 & 19 & \\
\hline
\end{tabular}

Notes: No. = tropical storm number in Fernandez-Partagas and Diaz (1995) (1851-1870) or HURDAT (1871-1997); Date $=$ date of landfall or closest approach to New England (Gregorian calendar); Sources = number of historical sources used; Rpts $=$ number of historical reports collected; Towns $=$ number of towns with sufficient information to assign an F-scale value; F - (no damage); F0, F1, F2, F3 = number of towns at the specified damage level; Fmax = maximum reported damage; n.d. = no wind damage; n.r. = no reports of wind damage. 
24000 USGS topographic map). A map of topographic exposure was created for each hurricane, using the reconstructed peak wind direction and an inflection angle of $6^{\circ}$. These maps were compiled to produce maps showing estimated mean return intervals for $\mathrm{F} 1+$ and F2 damage across the landscape.

\section{RESUlts}

\section{Actual damage}

Damage reports.-As expected, the number of reports and the completeness of the resulting damage maps were greater for recent and/or severe hurricanes (Table 4). In general the level of wind damage was consistent within reports and among reports for the same town; e.g., if house roofs were blown off (F2), barns were blown down too (F2). A total of 2710 reports were analyzed for all 67 hurricanes. Of these, 1135 individual towns were assigned F-scale values, of which 5 towns $(0.4 \%)$ received no damage, 116 towns $(10 \%)$ received $\mathrm{F} 0$ damage, 710 towns (63\%) received $\mathrm{F} 1$ damage, 285 towns $(25 \%)$ received $\mathrm{F} 2$ damage, and 19 towns $(1.6 \%)$ received F3 damage. The maximum reported damage for each hurricane was distributed as follows: 11 hurricanes $(16 \%)$ with no damage or no reported damage, 4 hurricanes $(6 \%)$ with F0 damage, 20 hurricanes (30\%) with F1 damage, 24 hurricanes $(36 \%)$ with $\mathrm{F} 2$ damage, and 8 hurricanes $(12 \%)$ with F3 damage.

Spatial patterns.-At a regional scale, patterns of damage for individual hurricanes were consistent with meteorological expectations: damage was usually greater to the right of the storm track, where wind velocities are normally higher, and the intensity of damage usually lessened along the storm track, as the hurricane weakened over land or cold ocean water (Fig. 4). At a subregional scale, some heterogeneity in Fscale values among towns was often observed, though the F-scale values for neighboring towns normally differed by no more than one damage class. Such heterogeneity may reflect differences in the quality of historical data as well as real differences in the severity of wind damage. A composite map displaying the highest level of damage reported for each town over the entire historical period (Fig. 4d) shows a regional gradient, with the most severe impacts along the southern coastline from New York City to Boston, and lesser impacts to the west and north.

Temporal patterns.-The timing of hurricane impacts varied widely in New England. There were four years $(1638,1869,1893,1954)$ in which two hurricanes in the same year caused major $(\mathrm{F} 1+)$ reported damage. Both hurricanes in 1869 caused F3 damage, though in different parts of the region (Table 4). From 1871 to 1997 (when meteorological records are complete), the mean interval between years in which hurricanes caused F1 + damage in New England was 6 yr, with a maximum of $21 \mathrm{yr}$ (note that these are regional values and do not apply to any given site).

On a decadal scale, the number of hurricanes causing significant damage $(\mathrm{F} 1+)$ in New England since 1871 also varied from a minimum of no storms in the $1910 \mathrm{~s}$ to a maximum of four storms in the 1950s (Fig. 5a). Historical evidence suggests that such variation was present over the entire historical period (Fig. 5). Decadal variation in the frequency of North Atlantic hurricanes since 1871 is well documented (e.g., Neumann et al. 1987), and there is a growing understanding of how this variation is linked to other global climatic factors (e.g., Gray 1990, Gray et al. 1997).

On a scale of centuries, there was no clear trend in the timing of hurricanes causing F3 damage (Fig. 5). At lower damage levels, fewer storms were recorded in the 17th and 18th centuries than in the 19th and 20th centuries. This difference is probably the result of improvements in meteorological observations and records since the early 19th century, especially since the difference is most pronounced for the weakest storms (F1 damage).

Analysis of seasonal distribution showed that most hurricanes occurred near the end of the growing season in New England, with about one quarter in October and November during or after leaf senescence (Fig. 6). Deciduous trees are much less likely to suffer wind damage in these fall storms, especially in northern New England where leaf fall occurs 3-4 wk earlier than in southern New England.

\section{Meteorological reconstructions}

Meteorological characteristics.-The intensity of the hurricanes studied ranged from category 1 to category 3 on the Saffir-Simpson scale at the point of landfall or closest approach to New England, based on the values used for $V_{\mathrm{m}}$ (maximum sustained wind speed) in the model reconstructions (Table 5). Twentythree hurricanes $(34 \%)$ were category $1\left(V_{\mathrm{m}}=33-42\right.$ $\mathrm{m} / \mathrm{s}), 34$ hurricanes $(51 \%)$ were category $2\left(V_{\mathrm{m}}=43-\right.$ $49 \mathrm{~m} / \mathrm{s})$, and 10 hurricanes $(15 \%)$ were category $3\left(V_{\mathrm{m}}\right.$ $=50-58 \mathrm{~m} / \mathrm{s})$. There was no indication of a change in maximum intensity over the historical period. Fortyone $(61 \%)$ of the hurricanes studied made landfall in New England, including $77 \%$ of the hurricanes before 1871 , and $49 \%$ of the hurricanes since 1871 . The difference in percentage of landfalls reflects the different criteria used to select hurricanes in the two periods, and the greater abundance of information about offshore hurricanes in the later period. The best-fit values for the radius of maximum winds were distributed as follows: $50 \mathrm{~km}=16$ hurricanes $(24 \%), 75 \mathrm{~km}=31$ hurricanes $(46 \%)$, and $100 \mathrm{~km}=20$ hurricanes $(30 \%)$.

Actual and reconstructed damage.-In nearly all cases there was good agreement between reconstructed and actual F-scale damage by town (Table 5). The overall distribution of difference values (reconstructed damage minus actual damage by town) was as follows: 

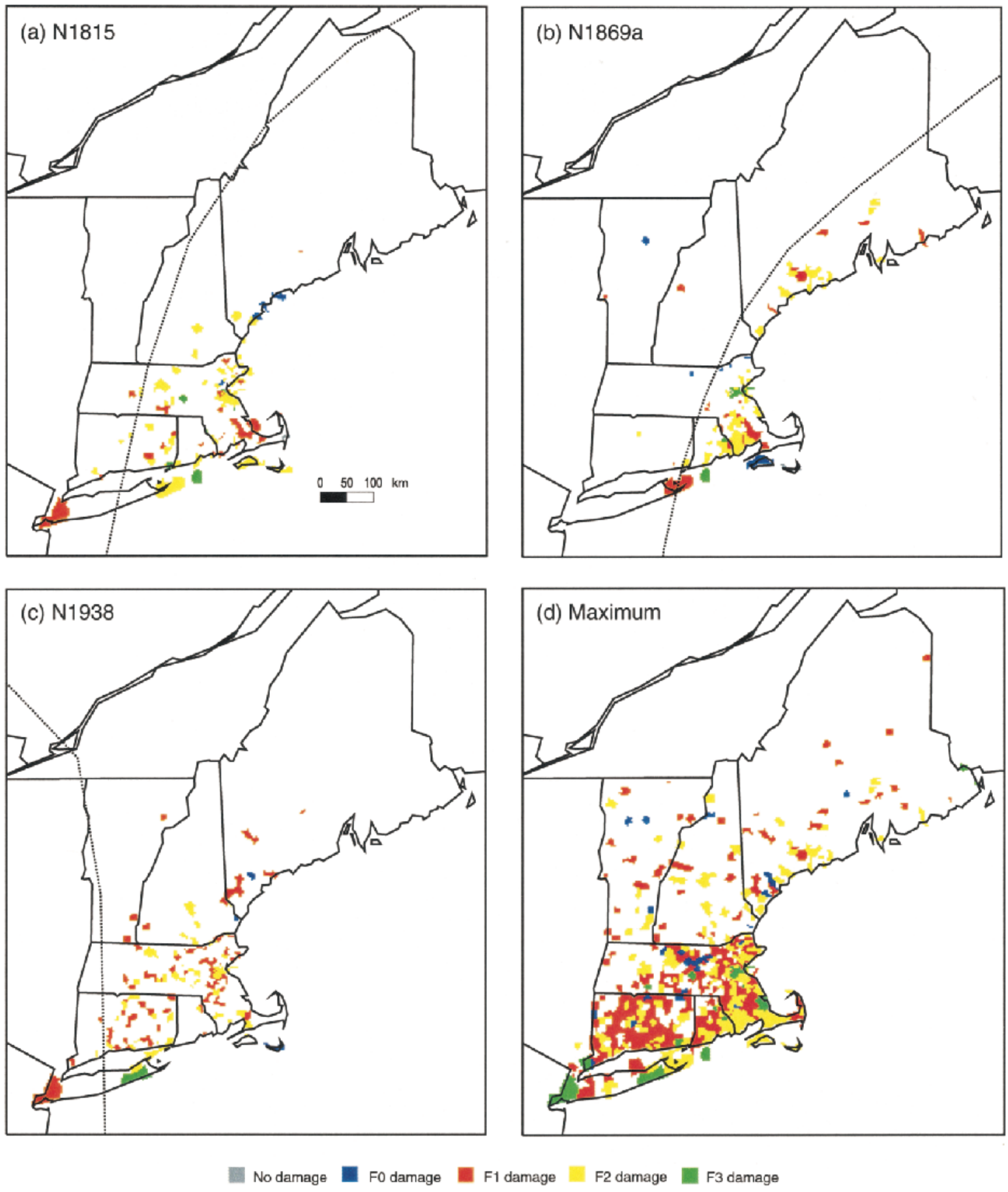

FIG. 4. Regional patterns of actual wind damage by town for selected major hurricanes: (a) N1815, (b) N1869a, (c) N1938, and (d) composite map showing the highest level of reported damage for each town in all 67 hurricanes studied.

two classes too low $=7$ towns $(0.6 \%)$, one class too low $=259$ towns $(23 \%)$, no difference $=684$ towns $(62 \%)$, one class too high $=153$ towns $(14 \%)$, and two classes too high $=7$ towns $(0.6 \%)$. Thus the reconstructed F-scale damage equaled the actual damage in $62 \%$ of the cases and was within one damage class in
$99 \%$ of the cases. Overall, there was a slight tendency to underestimate actual damage. In some cases the model also underestimated the level of damage on the left side of the storm track, particularly when the storm passed offshore. The highest level of reconstructed damage over land in all storms was F2. There was no 
a) All Hurricanes

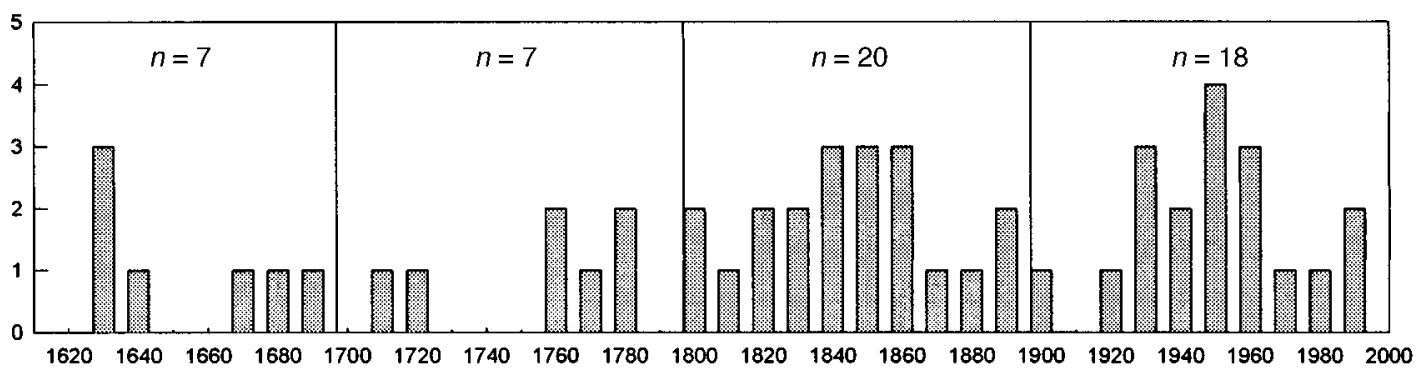

b) F3 Damage

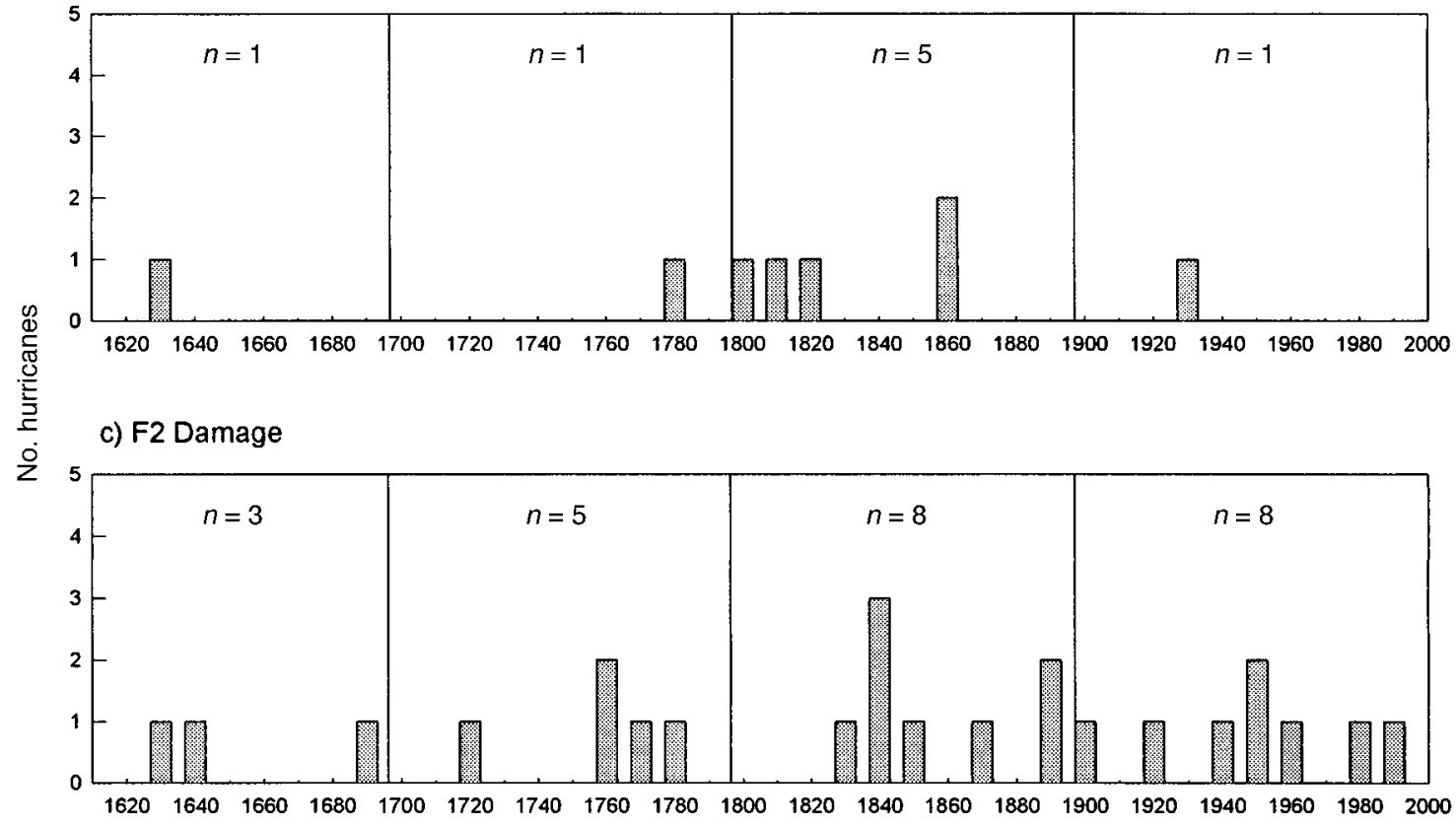

d) F1 Damage

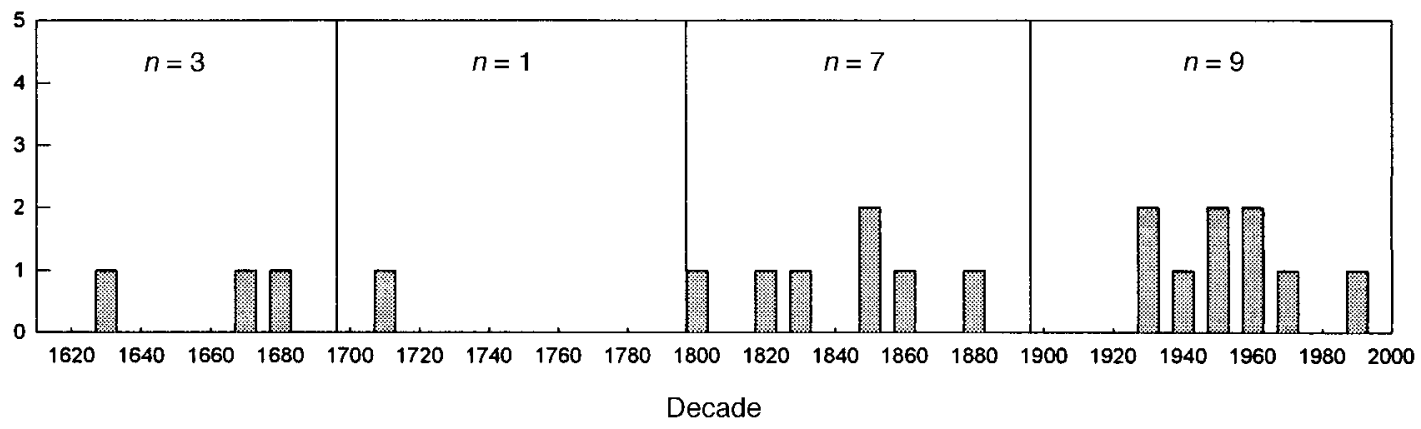

FIG. 5. Number of hurricanes by decade (1620-1997) over the entire study area with maximum reported damage on the Fujita scale equal to (a) F1 or higher, (b) F3, (c) F2, and (d) F1.

clear evidence of widespread F3 damage over land during the historical period, nor of sustained wind speeds high enough to produce such damage $(\geq 62 \mathrm{~m} / \mathrm{s})$ except perhaps along the coast.

Regional impacts.-As expected, estimated hurri- cane frequency varied across the three observation periods. For example, the estimated minimum return interval for $\mathrm{F} 0+$ events in New England was greatest for the period 1620-1997, suggesting that some of these events were not recorded in the early period; while the 


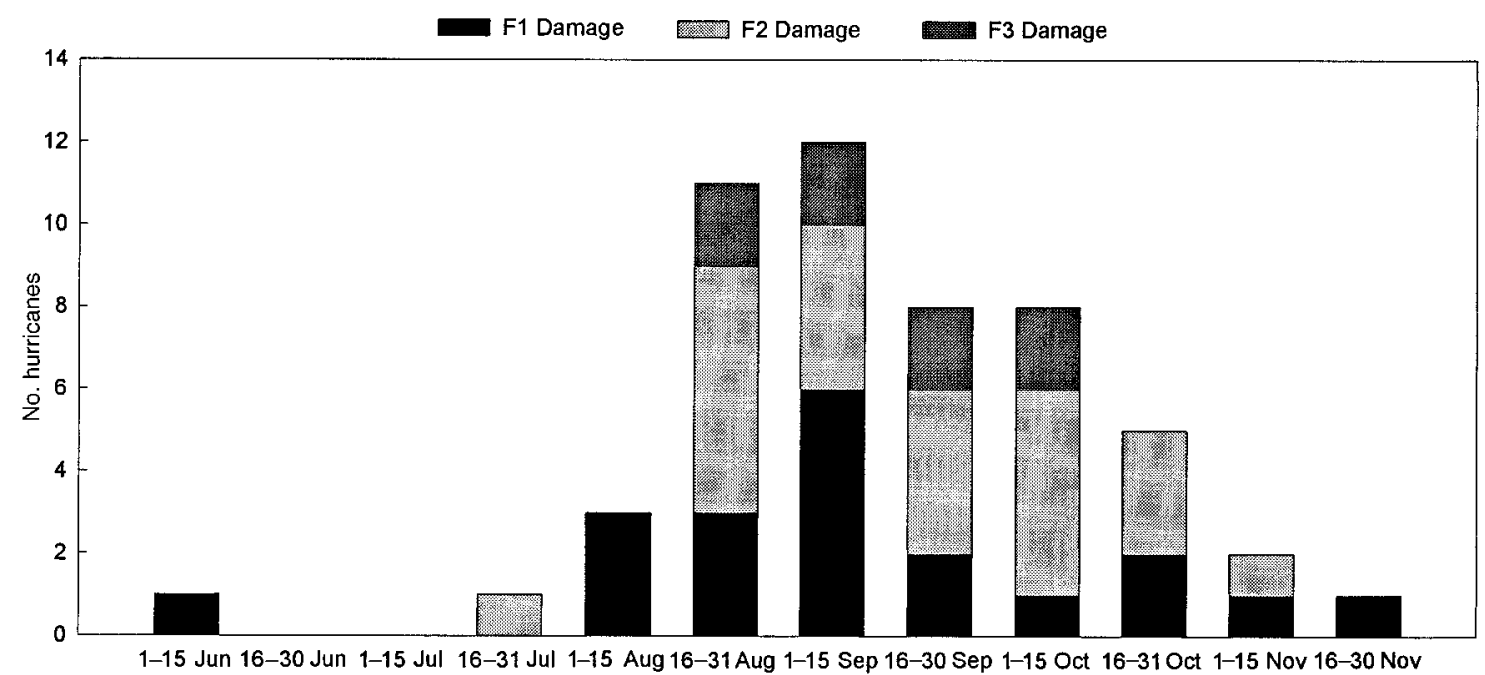

FIG. 6. Seasonal distribution of hurricanes with maximum reported damage on the Fujita scale of F1 or higher (16201997), showing the date of landfall or closest approach to New England (Gregorian calendar).

greatest variation occurred for F2 events, no doubt because of the small sample size (Table 6). Final results presented below for $\mathrm{F} 0+, \mathrm{F} 1+$, and $\mathrm{F} 2$ damage were based on the periods 1871-1997, 1800-1997, and 1620-1997, respectively, to maximize the observation period while still minimizing the likelihood that storms of a given magnitude escaped historical notice.

Composite maps of individual hurricane reconstructions, using best-fit values for radius of maximum winds, showed clear gradients of reconstructed frequency and intensity across New England (Fig. 7). Mean return intervals for F0 damage (loss of leaves and branches) or higher ranged from $5 \mathrm{yr}$ in Long Island and southeastern New England to $85 \mathrm{yr}$ in northwestern Vermont and northernmost Maine (Fig. 8a). Mean return intervals for F1 damage (scattered blowdowns, small gaps) or higher ranged from $10 \mathrm{yr}$ in Long Island and southeastern New England to $>200 \mathrm{yr}$ in northern Maine (Fig. 8b). Mean return intervals for F2 damage (extensive blowdowns, large gaps) ranged from $85 \mathrm{yr}$ in eastern Long Island and southeastern New England to $150 \mathrm{yr}$ in central Massachusetts and $>380 \mathrm{yr}$ across most of northern New England (Fig. 8c). Maximum reconstructed $\mathrm{F}$-scale damage showed much the same pattern, with values ranging from F2.5 in eastern Connecticut, Rhode Island, and southeastern Massachusetts to F0.0 in northernmost Maine (Fig. 7d). This map matches the map of maximum reported damage (Fig. $4 d$ ), except for the very high damage (F3) reported in the vicinity of New York City.

Analysis of model sensitivity to the parameter $R_{\mathrm{m}}$ (radius of maximum winds) yielded the following range of values for the maximum number of storms causing F2 damage over an area greater than one cell: four storms with $R_{\mathrm{m}}=50 \mathrm{~km}$, five storms with $R_{\mathrm{m}}=$ best fit, six storms with $R_{\mathrm{m}}=75 \mathrm{~km}$, and seven storms with $R_{\mathrm{m}}=100 \mathrm{~km}$; with corresponding mean return intervals of 95, 76, 63, and $54 \mathrm{yr}$, respectively (Fig. 9). Thus estimated return intervals for $R_{\mathrm{m}}=50 \mathrm{~km}$ and $R_{\mathrm{m}}=$ $100 \mathrm{~km}$ were within about $20 \mathrm{yr}$ or $25 \%$ of the bestfit value of $76 \mathrm{yr}$.

Site and landscape impacts.-Timelines of reconstructed F-scale damage for the town of Petersham, Massachusetts, and the city of Providence, Rhode Island, were generated using the best-fit values for the radius of maximum winds (Fig. 10). Though the temporal patterns are similar, there are important differences despite the fact that the sites are only $100 \mathrm{~km}$ apart. On average, Providence experiences more hurricanes and more severe hurricanes than Petersham, as one would expect from the regional gradients described above. For example, hurricane damage at the F2 level was estimated to occur three times in Petersham and five times in Providence over the historical period.

Peak hurricane wind directions were compared between Petersham and Providence, using the best-fit values for the radius of maximum winds (Fig. 11). The plot for Petersham showed a concentration of storms with peak winds from the northeast (i.e., storms passing to the east), while the highest winds came from the southeast (i.e., storms passing to the west). The plot for Providence was similar, with a somewhat greater fraction of storms with winds from the southeast, and one unusual storm with high winds from the southwest (N1804). At both sites peak hurricane winds were concentrated in certain directions.

The role of local topography in modifying hurricane wind impacts was investigated for Petersham with the EXPOS model (Fig. 12). For the 19 hurricanes that were estimated to cause F1+ damage, $74 \%$ of the landscape was predicted to be exposed to all 19 storms (mean return interval $=20 \mathrm{yr}), 20 \%$ was exposed to 10-18 storms (30 yr), and 6\% was exposed to 1-9 storms $(75 \mathrm{yr})$. For the three hurricanes that were es- 
TABLE 5. Meteorological characteristics of the 67 hurricanes investigated in this study, and comparisons between actual and reconstructed damage by town.

\begin{tabular}{|c|c|c|c|c|c|c|c|c|}
\hline \multirow{2}{*}{$\begin{array}{l}\text { Hurri- } \\
\text { cane }\end{array}$} & \multirow{2}{*}{$\begin{array}{l}\text { SS } \\
\text { Cat }\end{array}$} & \multirow[b]{2}{*}{ Track } & \multirow{2}{*}{$\begin{array}{l}R_{\mathrm{m}} \\
(\mathrm{km})\end{array}$} & \multicolumn{5}{|c|}{$\begin{array}{l}\text { Reconstructed damage minus } \\
\text { actual damage }\end{array}$} \\
\hline & & & & -2 & -1 & 0 & +1 & +2 \\
\hline N1635 & 3 & $\mathrm{~L}$ & 75 & & 1 & 1 & & \\
\hline N1638a & 2 & $\mathrm{~L}$ & 75 & & & 1 & & \\
\hline N1638b & 2 & $\mathrm{~L}$ & 50 & & 1 & & 1 & \\
\hline N1646 & 2 & $\mathrm{~L}$ & 100 & & 1 & & & \\
\hline N1675 & 2 & $\mathrm{~L}$ & 75 & & & 2 & 1 & \\
\hline N1683 & 1 & $\mathrm{~L}$ & 75 & & & 1 & & \\
\hline N1698 & 2 & $\mathrm{~L}$ & 75 & & 1 & & & \\
\hline N1716 & 2 & $\mathrm{O}$ & 75 & & & 1 & & \\
\hline N1727 & 2 & $\mathrm{~L}$ & 75 & & 3 & 3 & & \\
\hline N1761 & 2 & $\mathrm{~L}$ & 75 & & 4 & 2 & & \\
\hline N1769 & 2 & $\mathrm{~L}$ & 100 & & 1 & 2 & & \\
\hline N1770 & 2 & $\mathrm{~L}$ & 75 & & 2 & 1 & & \\
\hline N1785 & 2 & $\mathrm{O}$ & 100 & & 1 & & & \\
\hline N1788 & 3 & $\mathrm{~L}$ & 50 & & 13 & 8 & 4 & \\
\hline N1804 & 2 & $\mathrm{~L}$ & 75 & 1 & 6 & 10 & 2 & \\
\hline N1806 & 2 & $\mathrm{O}$ & 75 & & & 2 & 1 & \\
\hline N1815 & 3 & $\mathrm{~L}$ & 75 & & 13 & 50 & 25 & 2 \\
\hline N1821 & 3 & $\mathrm{~L}$ & 50 & & 5 & 18 & 9 & \\
\hline N1825 & 2 & $\mathrm{~L}$ & 75 & & & 1 & & \\
\hline N1830 & 2 & $\mathrm{O}$ & 75 & & 2 & 1 & & \\
\hline N1839 & 1 & $\mathrm{~L}$ & 75 & & 1 & 2 & & \\
\hline N1841 & 2 & $\mathrm{O}$ & 75 & & 2 & 5 & 2 & \\
\hline N1846 & 2 & $\mathrm{~L}$ & 100 & & 8 & 7 & & \\
\hline N1849 & 2 & $\mathrm{O}$ & 100 & & 2 & 1 & 1 & \\
\hline N1850 & 1 & $\mathrm{~L}$ & 75 & & 1 & 1 & & \\
\hline N1854 & 2 & $\mathrm{O}$ & 100 & & & 1 & & \\
\hline N1858 & 2 & $\mathrm{~L}$ & 75 & & & 2 & 3 & \\
\hline N1861 & 1 & $\mathrm{~L}$ & 100 & & & 1 & & \\
\hline N1869a & 3 & $\mathrm{~L}$ & 50 & & 13 & 48 & 19 & 5 \\
\hline N1869b & 3 & $\mathrm{~L}$ & 50 & & 2 & 1 & & \\
\hline N1878 & 1 & $\mathrm{~L}$ & 75 & & 1 & 1 & & \\
\hline N1888 & 2 & $\mathrm{O}$ & 75 & & & 1 & & \\
\hline N1891 & 2 & $\mathrm{O}$ & 50 & & & & & \\
\hline N1893a & 1 & $\mathrm{O}$ & 50 & & & & & \\
\hline N1893b & 2 & $\mathrm{~L}$ & 50 & & 1 & & 1 & \\
\hline N1893c & 1 & $\mathrm{~L}$ & 75 & & 2 & 2 & & \\
\hline N1896 & 1 & $\mathrm{~L}$ & 50 & & & 1 & 1 & \\
\hline N1903 & 1 & W & 100 & & 1 & 1 & & \\
\hline N1904 & 1 & $\mathrm{~L}$ & 75 & & & & & \\
\hline N1908 & 2 & $\mathrm{O}$ & 50 & & & & & \\
\hline N1916 & 1 & $\mathrm{~L}$ & 50 & & & & & \\
\hline N1924 & 3 & $\mathrm{O}$ & 100 & & 7 & 19 & & \\
\hline N1927 & 2 & $\mathrm{O}$ & 75 & & 1 & 1 & & \\
\hline N1933 & 1 & $\mathrm{O}$ & 100 & & 6 & 1 & & \\
\hline N1934 & 1 & $\mathrm{~L}$ & 100 & & 1 & & & \\
\hline N1936a & 1 & $\mathrm{~L}$ & 75 & & 4 & 2 & 1 & \\
\hline N1936b & 1 & $\mathrm{O}$ & 75 & & & & & \\
\hline N1938 & 3 & $\mathrm{~L}$ & 75 & & 22 & 66 & 37 & \\
\hline N1940 & 1 & $\mathrm{O}$ & 100 & & 1 & 1 & & \\
\hline N1944 & 2 & $\mathrm{~L}$ & 100 & & 10 & 37 & & \\
\hline N1950a & 2 & $\mathrm{O}$ & 50 & & & & & \\
\hline N1950b & 1 & $\mathrm{O}$ & 100 & 1 & & & & \\
\hline N1953a & 1 & $\mathrm{O}$ & 75 & & 1 & & & \\
\hline N1953b & 1 & $\mathrm{O}$ & 75 & & & & & \\
\hline N1954a & 2 & $\mathrm{~L}$ & 75 & & 19 & 57 & 3 & \\
\hline N1954b & 2 & $\mathrm{~L}$ & 100 & 1 & 8 & 6 & 1 & \\
\hline N1958 & 3 & $\mathrm{O}$ & 50 & & & & & \\
\hline N1960 & 2 & $\mathrm{~L}$ & 100 & & 4 & 33 & 3 & \\
\hline N1961 & 1 & $\mathrm{~L}$ & 50 & & & 6 & & \\
\hline N1962a & 2 & $\mathrm{O}$ & 50 & & & & & \\
\hline N1962b & 1 & $\mathrm{O}$ & 100 & & 1 & & & \\
\hline N1963 & 2 & $\mathrm{O}$ & 75 & 1 & & 1 & & \\
\hline N1969 & 3 & $\mathrm{~L}$ & 50 & & & 1 & & \\
\hline N1976 & 1 & $\mathrm{~L}$ & 100 & & 5 & 4 & & \\
\hline
\end{tabular}

TABle 5. Continued.

\begin{tabular}{|c|c|c|c|c|c|c|c|c|}
\hline \multirow{2}{*}{$\begin{array}{l}\text { Hurri- } \\
\text { cane }\end{array}$} & \multirow{2}{*}{$\begin{array}{l}\text { SS } \\
\text { Cat }\end{array}$} & \multirow[b]{2}{*}{ Track } & \multirow{2}{*}{$\begin{array}{c}R m \\
(\mathrm{~km})\end{array}$} & \multicolumn{5}{|c|}{$\begin{array}{l}\text { Reconstructed damage minus } \\
\text { actual damage }\end{array}$} \\
\hline & & & & -2 & -1 & 0 & +1 & +2 \\
\hline N1985 & 2 & $\mathrm{~L}$ & 75 & 3 & 41 & 47 & 7 & \\
\hline N1991 & 2 & $\mathrm{~L}$ & 100 & & 38 & 219 & 31 & \\
\hline N1996 & 1 & $\mathrm{O}$ & 100 & & 2 & 4 & & \\
\hline Totals & & & & 7 & 259 & 684 & 153 & 7 \\
\hline
\end{tabular}

Notes: SS Cat $=$ Saffir-Simpson category at landfall or closest approach to New England. Track = landfall (L), offshore $(\mathrm{O})$, or passed to west (W) of New England. $R_{\mathrm{m}}=$ bestfit radius of maximum winds. Values in rightmost columns show the number of towns for the specified value of reconstructed damage minus actual damage on the Fujita scale.

timated to cause $\mathrm{F} 2$ damage, $82 \%$ of the landscape was predicted to be exposed to all three storms (125 yr), $10 \%$ was exposed to two storms (190 yr), 6\% was exposed to one storm (380 yr), and $2 \%$ was protected from all 3 storms $(>380 \mathrm{yr})$. This analysis suggests a significant landscape-level gradient of hurricane impacts within the larger regional gradient, though most of the gently rolling terrain of Petersham was predicted to be fully exposed to all storms.

DISCUSSION

\section{Historical-modeling method}

Historical completeness.-Perhaps the most difficult problem in using historical materials to reconstruct hurricane regimes is estimating the completeness of the early records. In New England, it is possible that all records of a storm in the first few decades after settlement were lost, particularly if impacts were confined to sparsely settled areas such as the far eastern coast of Maine. On the other hand, there was considerable traffic at sea even in the early 17 th century, increasing the likelihood that major hurricanes were not overlooked (cf. Lamb 1991). We find numerous accounts of the first storm on record (N1635) from ships at sea and from points along the coast of Maine and Nova Scotia, fifteen years after the first European settlers arrived in New England. And observers often compared the current storm to other storms within living memory, suggesting the lack of comparable storms (at those locations, at least) during the intervening years. The probability that a hurricane was overlooked is no doubt

TABLE 6. Reconstructed hurricane frequencies for three historical time periods, using best-fit values for the radius of maximum winds.

\begin{tabular}{cccccc}
\hline \hline Dates & Years & $\begin{array}{c}\text { Hurri- } \\
\text { canes }\end{array}$ & F0+ & F1+ & F2 \\
\hline $1620-1997$ & 378 & 67 & 6 & 11 & 76 \\
$1800-1997$ & 198 & 53 & 4 & 9 & 50 \\
$1871-1997$ & 127 & 37 & 4 & 12 & 127 \\
\hline
\end{tabular}

Note: Values in rightmost columns are minimum mean return intervals in years over the entire study area for $\mathrm{F} 0+$, $\mathrm{F} 1+$, and F2 wind damage on the Fujita scale. 

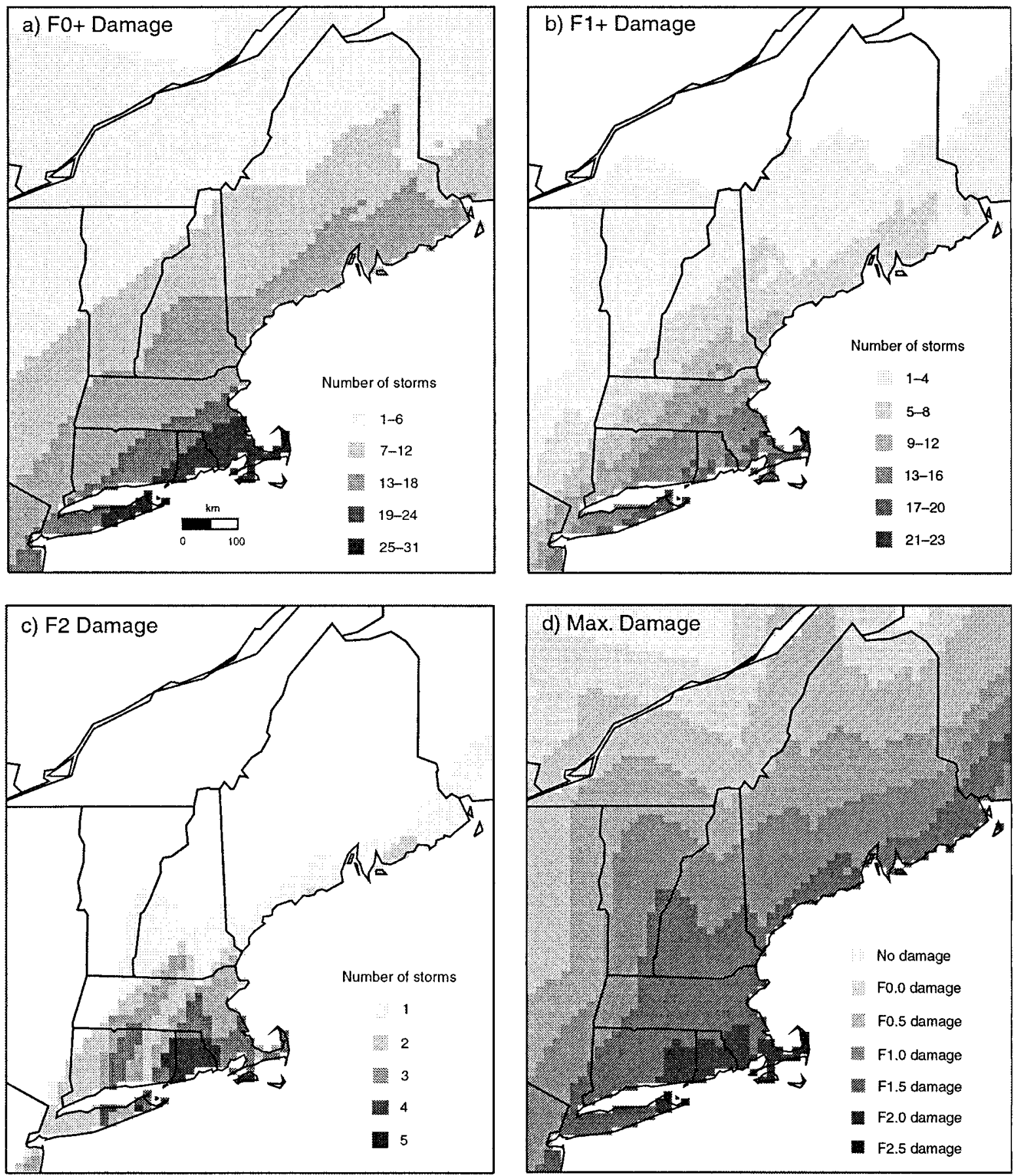

FIG. 7. Regional gradients in reconstructed hurricane damage, using best-fit values for the radius of maximum winds: (a) F0+ damage (1871-1997); (b) F1+ damage (1800-1997); (c) F2 damage (1620-1997); and (d) maximum damage on the Fujita scale in 0.5 class increments (1620-1997).

greatest for minimal hurricanes during the earliest period, which is why we relied on more recent time periods for assessing weaker events in this study.

Damage assessment.-In this study, Fujita-scale values were assigned to entire towns on the basis of historical reports of wind damage. Potential sources of error include: (1) Damage levels may be overestimated if the object damaged (e.g., a tree or a house) was weak or defective before the storm, or if severe damage on a smaller scale (e.g., caused by a tornado embedded in the hurricane) is generalized to an entire town. Failure to exclude damage caused by storm surge or river flood- 

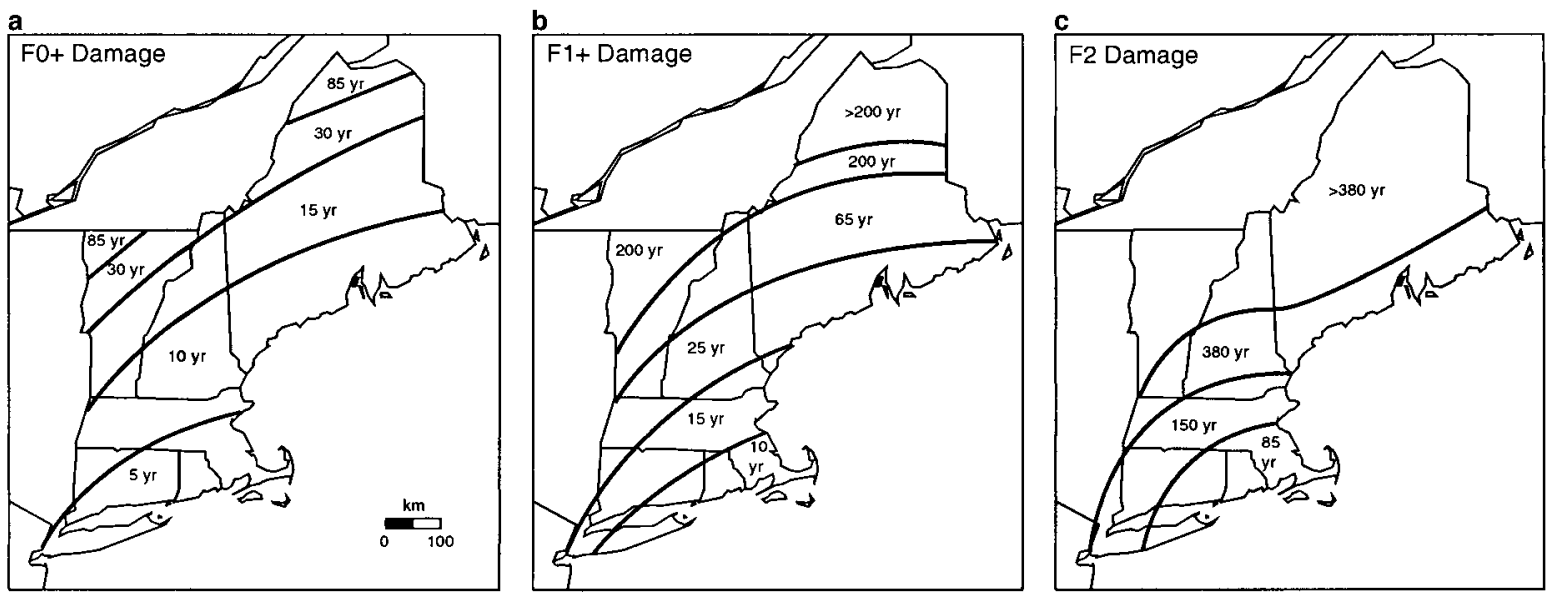

FIG. 8. Smoothed regional gradients in reconstructed hurricane damage, using best-fit values for the radius of maximum winds: mean return intervals for (a) F0+ damage (1871-1997), (b) F1+ damage (1800-1997), and (c) F2 damage (16201997).

ing may also lead to overestimation of the level of wind damage for coastal or valley towns. (2) Damage levels may be underestimated if suitable objects are not present in the area surveyed (e.g., if only barns and outbuildings are present, then the highest possible level of damage to buildings is F2), or if examples of higher damage are not observed and reported (e.g., in sparsely populated areas). F-scale values may be higher for larger towns and cities than in the surrounding countryside because there are more observers, more property subject to potential damage, and better records. (3) Systematic errors may occur because of differences in construction practices over time, or from place to place. The susceptibility of a particular building to wind damage is a complex function of building design and construction quality, as well as state of repair, wind direction, topographic position, surrounding wind breaks, and whether or not doors and windows are open, closed, or shuttered (Liu 1993). However this information is generally unavailable from historical sources. Finally, (4) random errors may result from inaccuracies in the historical accounts.

The problems described above arise mainly from the need to rely on written records and photographs for damage assessment. However the basic technique was found to work well for the purposes of this study, largely because the Fujita damage classes are so broad. The inclusion of all tree blowdowns as F1 and even partial house roof removals as F2 (required by the nature of the historical reports) may have contributed to the slight overall tendency for the model to underestimate actual wind damage.

Meteorological modeling.-Meteorological modeling complements wind damage assessment by provid-
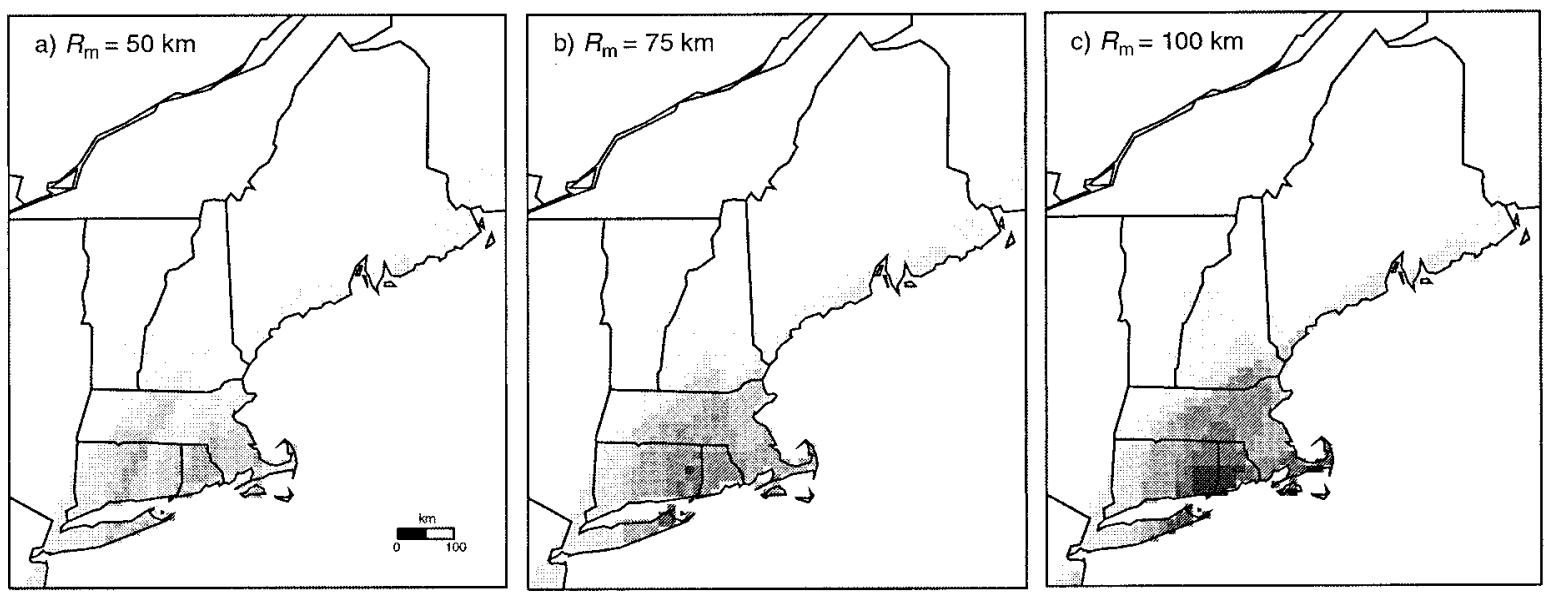

1 storm

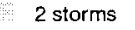

3 storms 4 storms 5 storms

FIG. 9. Regional gradients in reconstructed F2 damage (1620-1997), for different fixed values of the radius of maximum winds: (a) $R_{\mathrm{m}}=50 \mathrm{~km}$; (b) $R_{\mathrm{m}}=75 \mathrm{~km}$; (c) $R_{\mathrm{m}}=100 \mathrm{~km}$. 
a) Petersham, MA

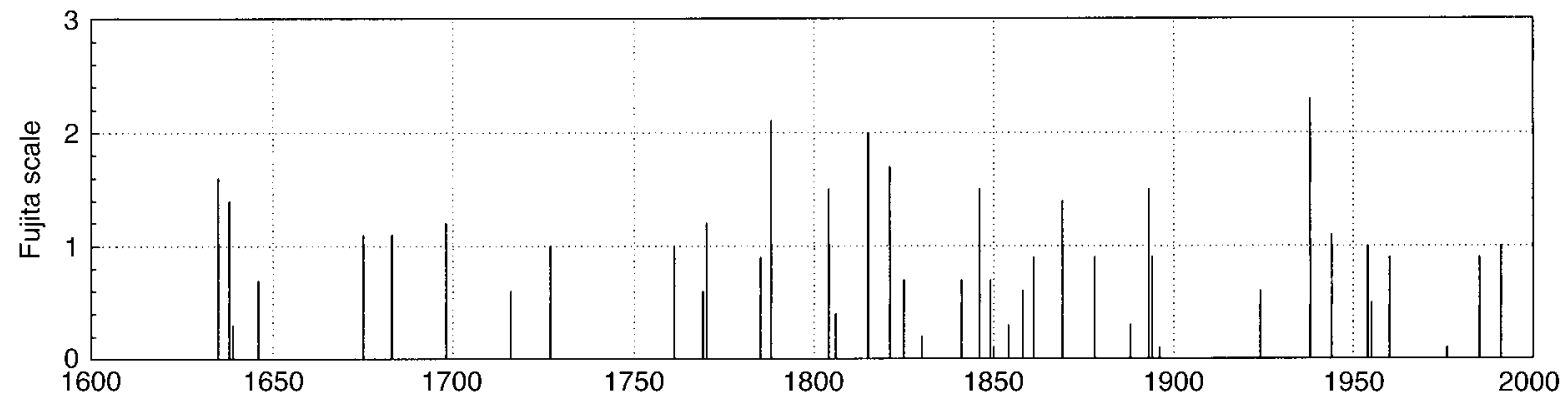

b) Providence, RI

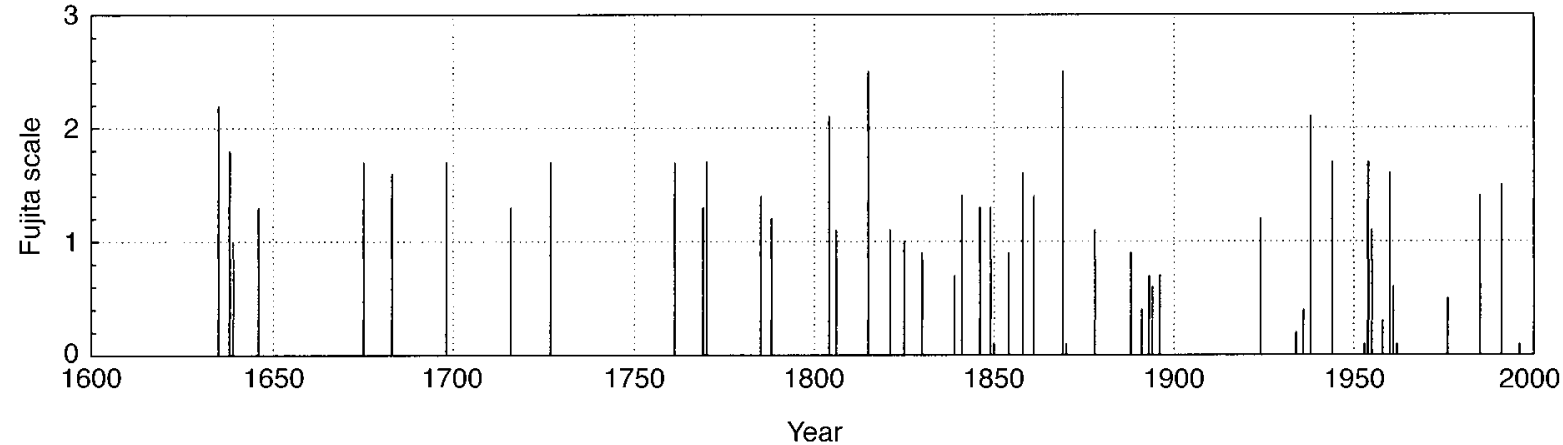

FIG. 10. Timelines of reconstructed hurricane damage on the Fujita scale by year for (a) Petersham, Massachusetts, and (b) Providence, Rhode Island.

a) Petersham, MA

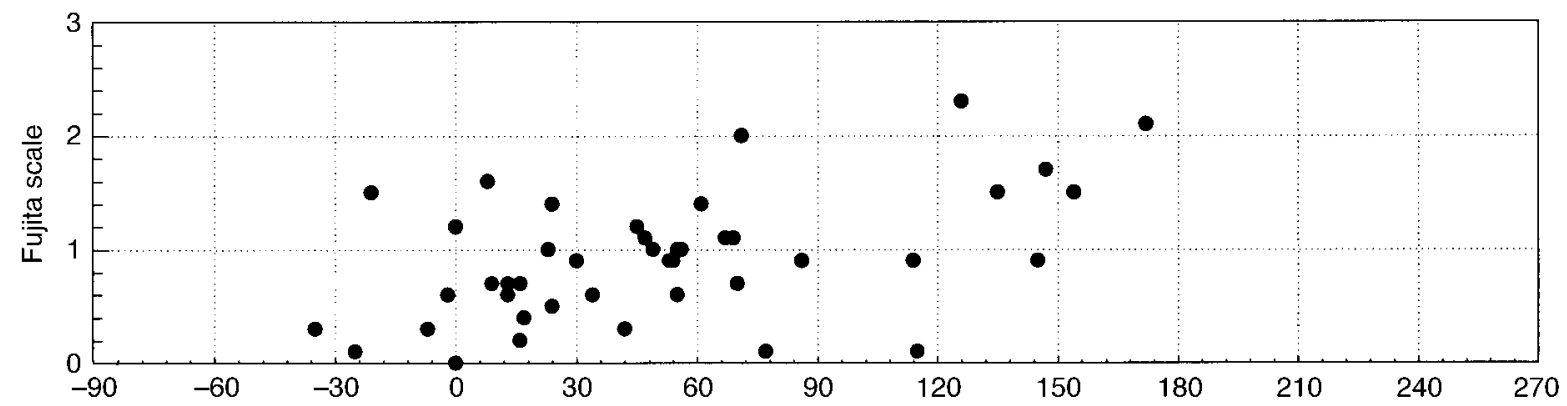

b) Providence, RI

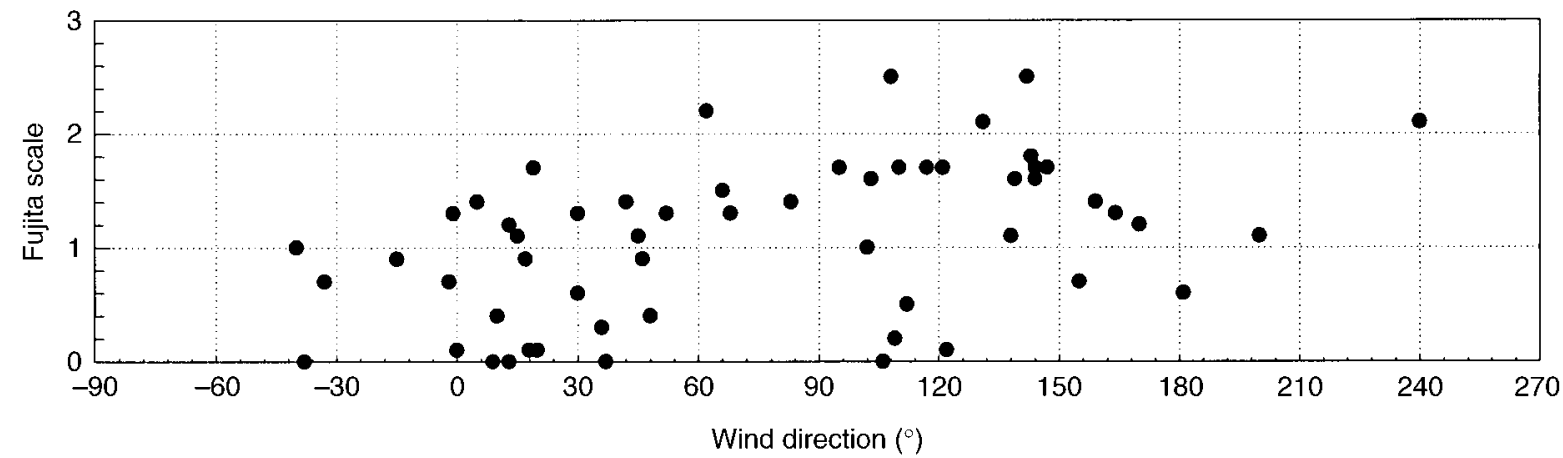

FIG. 11. Reconstructed hurricane damage on the Fujita scale by peak wind direction for (a) Petersham, Massachusetts, and (b) Providence, Rhode Island (1620-1997). Each point represents one hurricane. 
ing informed estimates for sites that lack actual observations, as well as a complete picture of the estimated impacts of each hurricane on a regional scale. Potential sources of error include: (1) The HURRECON model is based on an idealized wind profile that works best for intense hurricanes and less well for decaying hurricanes or hurricanes becoming extratropical storms. The model is not able to reconstruct multiple wind maxima or other mesoscale features (Willoughby 1995). (2) Damage estimates were based on peak 1/4 mile wind speed following Fujita's method (1971), which assumes that the period of sustained wind required to produce specific damage is inversely proportional to wind speed. This approach yields wind durations appropriate for tree and building damage (e.g., $12 \mathrm{~s}$ for minimal hurricane force winds), but does not take into account fatigue and stress damage that may occur on a scale of minutes or hours. (3) Uncertainties in input data (hurricane track, size, and intensity) are much greater for the early hurricanes, especially in sparsely populated areas.

In this study, input data accuracy increased by about an order of magnitude over the historical period. HURDAT gives hurricane positions to the nearest tenth of a degree $( \pm 5 \mathrm{~km})$ and maximum wind speeds to the nearest 5 knots $( \pm 1.3 \mathrm{~m} / \mathrm{s})$, while the corresponding uncertainties for the earliest storms are closer to \pm 100 $\mathrm{km}$ and $\pm 10 \mathrm{~m} / \mathrm{s}$. Less information was generally available for Cape Cod, Martha's Vineyard and Nantucket, the Maine coast, and northern New England; so uncertainties are greatest for early hurricanes in these areas.

Despite these problems, regional maps of actual and reconstructed damage were found to agree closely for hurricanes since 1871, for which meteorological and damage data were independent. This agreement was no doubt enhanced by the small number of predicted damage classes (no damage, F0, F1, F2); a larger number of classes would provide a more robust test of the model, but was not practical given the nature of the historical materials. For hurricanes before 1871, model reconstructions were consistent with available wind and damage data.

Mean return intervals were clearly affected by sample size. For example, the number of hurricanes estimated to cause widespread F0+ damage in New England since 1871 (34 storms) or widespread F1+ damage since 1800 (34 storms) was large enough to create fairly smooth maps of reconstructed frequency (Fig. 7a and b). However the number of hurricanes estimated to produce widespread F2 damage since 1620 was small enough ( 9 storms) that the maps of reconstructed frequency (Figs. 7c and 9) were relatively coarse and the area of highest estimated frequency shifted from eastern Long Island and Connecticut to Cape Cod with different values of the radius of maximum winds.

\section{Ecological significance for New England}

Regional impacts.-Historical gradients in hurricane frequency and intensity across New England result from the consistent direction of the storm tracks, the shape of the coastline, and the tendency for hurricanes to weaken rapidly over land or over cold ocean water north of the Gulf Stream. These regional gradients are strong enough to have significant ecological implications. For example, the historical record suggests that hurricane impacts have been minimal in northern New England, especially northernmost Maine, where F1+ damage has not occurred over the last $200 \mathrm{yr}$. On the other hand, southeastern New England experienced $\mathrm{F} 1+$ damage about every $10 \mathrm{yr}$ on average and F2 damage about every $85 \mathrm{yr}$. In these areas, a significant portion of the forest will experience blowdowns, with gap formation and recovery, on a scale of centuries. The major hurricanes may limit the maximum size and life span of susceptible species such as white pine ( $P i$ nus strobus) on exposed sites, and the combination of major and minor storms will cause most trees to experience some wind damage during their lifetimes. Because hurricanes are not evenly spaced in time, actual return intervals are sometimes much shorter than mean values and on rare occasions trees may be damaged twice in the same season.

At a regional scale, the impact of these gradients is controlled in part by broad-scale differences in natural vegetation and in land use and disturbance history. For example, forests on the immediate coastline and at higher elevations are routinely subject to higher wind speeds and may be more resilient to wind damage than forests in surrounding areas, though they are also subject to higher winds during a hurricane. The sprucefir forests of northern New England and the Maine coast, though less exposed to hurricane damage on average, are more likely to experience fires after a major hurricane than the hardwood forests of southern New England, where fewer fine fuels are generated and decomposition is faster. Forests closer to population centers are more likely to see blowdowns salvaged (for timber or fire prevention) after a major hurricane. And areas that have been cleared for agriculture or development, or whose forests are shorter in stature because of recent cutting, will tend to suffer less damage than areas with mature forest.

These results allow us to broaden our appreciation for the range of ecological roles that hurricanes may play in controlling forest structure and function. Emphasis in the ecological and forestry literature is generally placed on the catastrophic effect of hurricanes as they blow down extensive areas and create new, even-aged forests. Indeed our analysis identifies such occasional damage as important across southern and central New England and coastal Maine. However, hurricanes play another important role as a much more frequent and less intensive disturbance factor gener- 


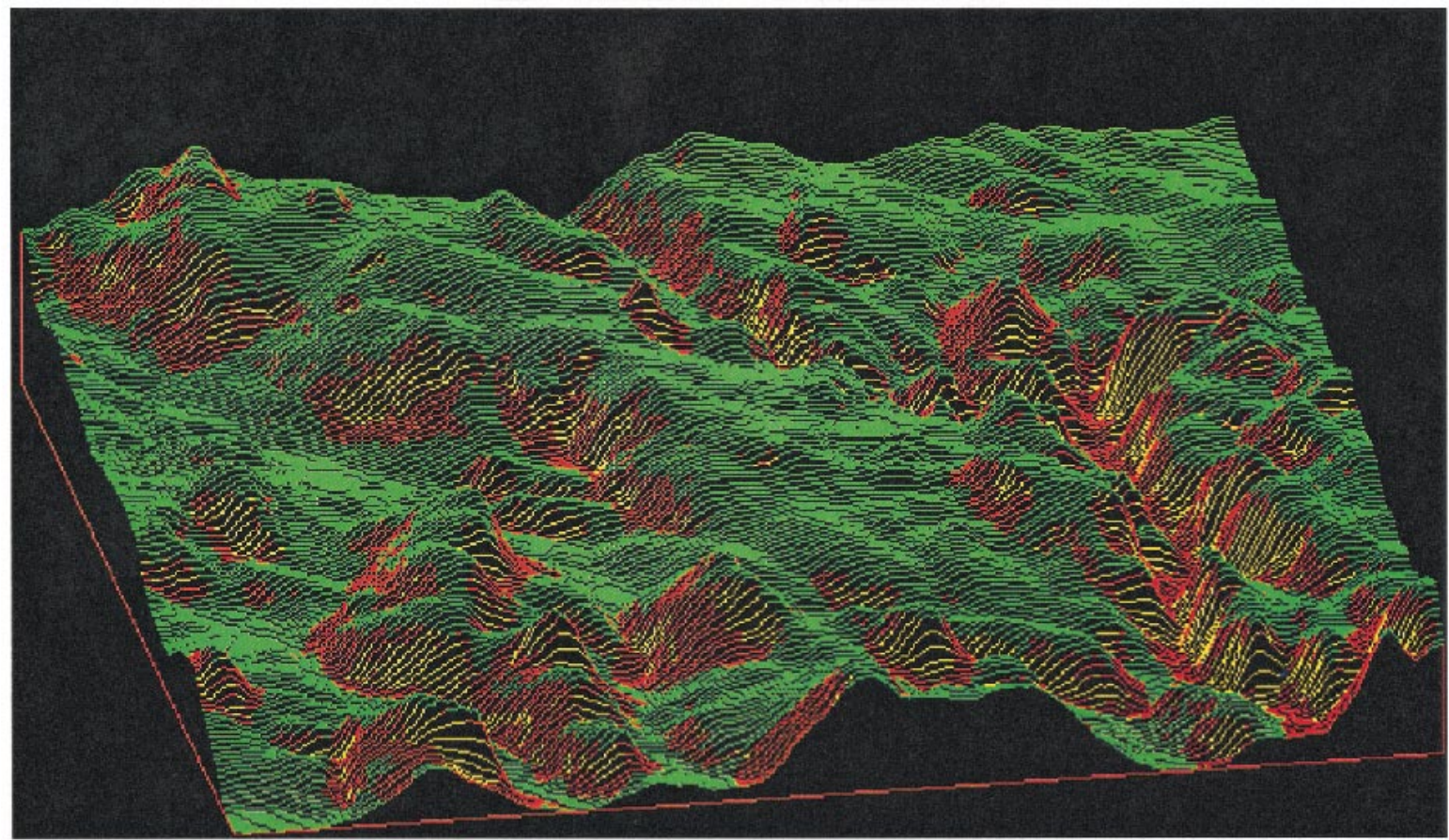

(a) F1+ Damage

$>380 \mathrm{yr}$

$75 \mathrm{yr}$

$30 \mathrm{yr}$

$20 \mathrm{yr}$

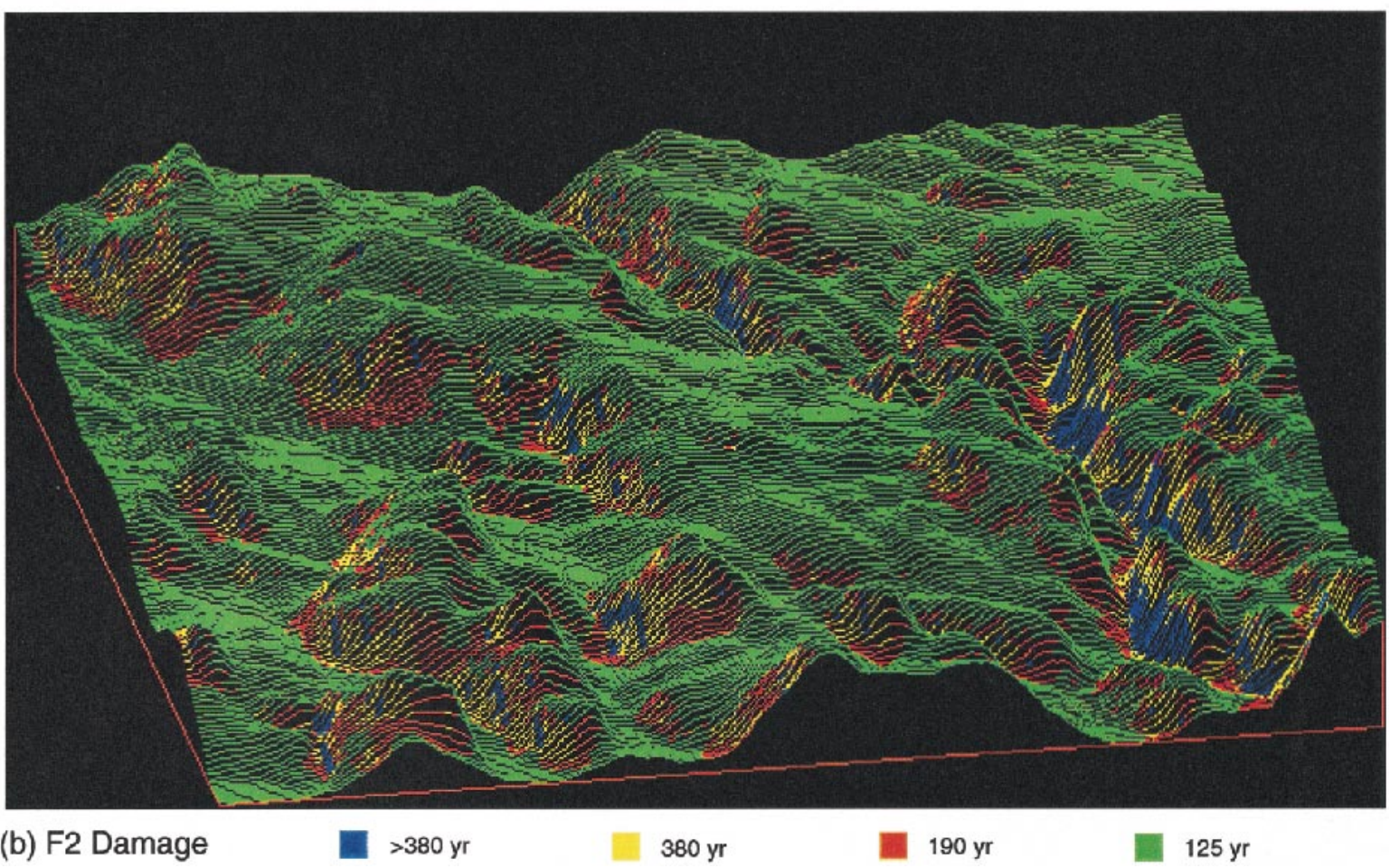

FIG. 12. Landscape gradients in reconstructed hurricane damage for the town of Petersham, Massachusetts (1620-1997), using the EXPOS model: (a) mean return intervals for F1+ damage; (b) mean return intervals for F2 damage.

ating small individual tree gaps, crown damage, branch break, and leaf stripping. Such damage is widespread and frequent across the region.

Site and landscape impacts.-_On a landscape scale, in hilly or mountainous terrain, local topography may protect certain areas from wind damage from a given direction. Such protection may be long-term if the damaging winds tend to come from the same direction in 
most or all hurricanes. In New England, the most damaging winds normally come from the southeast because of the direction of the storm tracks, the rapid forward motion of the storms, and the inward spiraling of winds at the surface. The size and spatial distribution of protected areas depends on the interaction between wind direction and local topography. In the gently rolling landscape of central New England around Petersham, areas predicted to have reduced long-term exposure to damaging winds were confined to relatively small patches in protected valleys and lee hillsides. Of course, the more subtle effects of this long-term protection on the vegetation are difficult to resolve in a landscape that has been so greatly affected by human activity in recent centuries.

The response of forest stands to winds of a given speed and duration varies considerably as a function of stand composition and structure. In the 1938 hurricane, conifer stands at Harvard Forest (mostly white pine) sustained greater damage than hardwood stands of the same height and exposure, while damage increased with stand height (Foster and Boose 1992). Thus site conditions and disturbance history play a critical role in determining forest response to wind. In central New England, for example, the two most powerful hurricanes since European settlement (N1815 and N1938) had different impacts on forests because of significant differences in land use history. In 1815, only $\sim 15 \%$ of the landscape was forested, and some of that was probably sprout growth of low stature and low susceptibility to wind damage. In contrast, much of the landscape in 1938 was forested, and there was an unusual abundance of mature, old-field white pine that was highly susceptible to wind damage. Thus, while the two storms were of comparable strength and had similar impacts on man-made structures, the hurricane of 1938 probably caused greater damage to forests in terms of the percentage of blowdowns and the fraction of the landscape affected.

No historical hurricanes in New England were powerful enough to blow down all the trees over extensive areas. At the scale of individual trees, damage is quite heterogeneous, and even the most severe storms in New England, capable of producing extensive blowdowns, produce many more examples of lesser damage such as individual treefall, branch break, and defoliation. The distribution of damage patch size tends to be highly skewed, with a preponderance of small patches (Foster and Boose 1992). The long-term impacts of blowdowns may include changes in structure and composition, coarse woody debris, microtopography, and soil nutrient processes, as well as greater susceptibility to fire (Foster et al. 1997). The effects of repeated minor damage (loss of leaves and small branches) are not well understood, but may be significant when combined with other stresses such as drought or disease.

Future impacts.-Present understanding of hurricane meteorology is not sufficient to predict the effects of climate change on hurricane frequency and intensity on theoretical grounds alone. If sea surface temperatures increase with global warming, for example, then the theoretical upper limit on hurricane intensity will increase, but the effects on mean hurricane intensity, frequency, and size are unclear. There is no evidence that the regions currently impacted by hurricanes will undergo expansion or contraction (Emanuel 1997). Some global modeling results actually show a decrease in predicted hurricane frequency under a doubled $\mathrm{CO}_{2}$ regime, in part because of a predicted increase in vertical wind shear over the portions of the tropical oceans where hurricanes form (Bengtsson et al. 1997). An alternative, empirical approach to the problem is to compare the hurricane and climate regimes of the past. The historical-modeling method presented here can be used to help calibrate and interpret various techniques for studying prehistoric hurricanes such as the stratigraphic analysis of salt marsh deposits (e.g., Bravo et al. 1997). Though future climate change might lead to changes in hurricane frequency and intensity over New England, the gradient patterns identified in this study, resulting from storm track direction, coastline geography, and hurricane weakening over land or cold water, would probably persist.

\section{Application to other regions}

The historical-modeling method makes it possible to quantify hurricane disturbance regimes in coastal forests, and can be applied to any part of the world where good historical records survive. The information obtained in this way can be combined with knowledge of other disturbance events to build a comprehensive disturbance history for a site or region. It can also be combined with other techniques to help interpret evidence of prehistoric hurricanes. The main disadvantage of the approach is the time and effort required to locate and assess the historical materials. In some areas it may also be necessary to adapt or extend the Fujita scale damage specifications to account for local building practices and local vegetation.

\section{ACKNOWLEDGMENTS}

The authors thank S. Baker and M. Feldberg for assistance with the historical research; S. Fitzgerald, M. Serrano, and B. Slater for help with the GIS analysis and figure preparation; $\mathrm{H}$. Willoughby for supplying aerial reconnaissance data; and E. Johnson, S. Jackson, and an anonymous reviewer for invaluable comments on the manuscript. The research was supported by grants from the National Science Foundation (DEB9318552 and DEB-9411975) and is a contribution from the Harvard Forest Long-Term Ecological Research Program.

\section{Literature Cited}

Bengtsson, L., M. Botzet, and M. Esch. 1997. Numerical simulation of intense tropical storms. Pages 67-90 in H. F. Diaz and R. S. Pulwarty, editors. Hurricanes: climate and socioeconomic impacts. Springer-Verlag, New York, New York, USA

Boose, E. R., K. E. Chamberlin, and D. R. Foster. 1997. Reconstructing historical hurricanes in New England. Pages 388-389 in Preprints of the 22nd conference on hurri- 
canes and tropical meteorology. American Meteorological Society, Boston, Massachusetts, USA.

Boose, E. R., D. R. Foster, and M. Fluet. 1994. Hurricane impacts to tropical and temperate forest landscapes. Ecological Monographs 64:369-400.

Bravo, J., J. P. Donnelly, J. Dowling, and T. Webb. 1997. Sedimentary evidence for the 1938 hurricane in southern New England. Pages 395-396 in Preprints of the 22nd conference on hurricanes and tropical meteorology. American Meteorological Society, Boston, Massachusetts, USA.

Darling, N. 1842. Notice of a hurricane that passed over New England in September, 1815. American Journal of Science and Arts 42:243-252.

Diaz, H. F., and R. S. Pulwarty, editors. 1997. Hurricanes: climate and socioeconomic impacts. Springer-Verlag, New York, New York, USA.

Dunn, G. E., and B. I. Miller. 1964. Atlantic hurricanes. Revised edition. Louisiana State University Press, Baton Rouge, Louisiana, USA.

Eastman, J. R. 1997. IDRISI for Windows, version 2.0. Clark University, Department of Geography, Worcester, Massachusetts, USA.

Emanuel, K. A. 1997. Climatic variations and hurricane activity: some theoretical issues. Pages 55-65 in H. F. Diaz and R. S. Pulwarty, editors. Hurricanes: climate and socioeconomic impacts. Springer-Verlag, New York, New York, USA.

Fernandez-Partagas, J., and H. F. Diaz. 1995. A reconstruction of historical tropical cyclone frequency in the Atlantic from documentary and other historical sources 1851 to 1880. Part I (1851-1870) and Final Report. Climate Diagnostics Center, National Oceanographic and Atmospheric Administration, Washington, D.C., USA.

Foster, D. R. 1983. The history and pattern of fire in the boreal forest of southeastern Labrador. Canadian Journal of Botany 61:2459-2471.

Foster, D. R., and J. D. Aber, editors. 2001. Forests in time: the environmental consequences of 1000 years of change in New England. Oxford University Press, Oxford, UK.

Foster, D. R., J. D. Aber, J. M. Melillo, R. D. Bowden, and F. A. Bazzaz. 1997. Forest response to disturbance and anthropogenic stress: rethinking the 1938 Hurricane and the impact of physical disturbance vs. chemical and climate stress on forest ecosystems. BioScience 47(7):437-445.

Foster, D. R., and E. R. Boose. 1992. Patterns of forest damage resulting from catastrophic wind in central New England, U.S.A. Journal of Ecology 80:79-98.

Foster, D. R., and E. R. Boose. 1995. Hurricane disturbance regimes in temperate and tropical forest ecosystems. Pages 305-339 in M. P. Coutts and J. Grace, editors. Wind and trees. Cambridge University Press, Cambridge, UK.

Foster, D. R., D. H. Knight, and J. F. Franklin. 1998. Landscape patterns and legacies resulting from large, infrequent forest disturbances. Ecosystems 1:497-510.

Fujita, T. T. 1971. Proposed characterization of tornadoes and hurricanes by area and intensity. Satellite and Mesometeorology Research Project Research Paper 91. University of Chicago, Chicago, Illinois, USA.

Fujita, T. T. 1987. U.S. Tornadoes: Part one, 70-year statistics Satellite and Mesometeorology Research Project Research Paper 218. University of Chicago, Chicago, Illinois, USA.

Gray, W. M. 1990. Strong association between West African rainfall and U.S. landfalling intense hurricanes. Science 249:1251-1256.

Gray, W. M., J. D. Sheaffer, and C. W. Landsea. 1997. Climate trends associated with multidecadal variability of Atlantic hurricane activity. Pages $15-53$ in H. F. Diaz and R. S. Pulwarty, editors. Hurricanes: climate and socioeconomic impacts. Springer-Verlag, New York, New York, USA.
Grazulis, T. P. 1993. Significant tornadoes 1680-1991. Environmental Films, St. Johnsbury, Vermont, USA.

Heinselman, M. L. 1973. Fire in the virgin forests of the Boundary Waters Canoe Area, Minnesota. Quaternary Research 3:329-382.

Henry, J. D., and J. M. A. Swan. 1974. Reconstructing forest history from live and dead plant material-an approach to the study of forest succession in southwest New Hampshire. Ecology 55:772-783.

Holland, G. J. 1980. An analytical model of the wind and pressure profiles in hurricanes. Monthly Weather Review 108:1212-1218.

Houston, S. H., and M. D. Powell. 1993. Surface wind fields during Hurricane Bob's (1991) landfall in New England. Pages 58-61 in Preprints of the 20th conference on hurricanes and tropical meteorology. American Meteorological Society, Boston, Massachusetts, USA.

Hunter, M. L. 1993. Natural fire regimes as spatial models for managing boreal forests. Biological Conservation 65 : $115-120$.

Johnson, E. A. 1992. The ecology of fire in the boreal forest. Cambridge University Press, Cambridge, UK.

Lamb, H. 1991. Historic storms of the North Sea, British Isles and northwestern Europe. Cambridge University Press, Cambridge, UK.

Liu, H. 1993. Calculation of wind speeds required to damage or destroy buildings. Pages 535-541 in C. Church, D. Burgess, C. Doswell, and R. Davies-Jones, editors. The tornado: its structure, dynamics, prediction, and hazards. Geophysical Monograph 79. American Geophysical Union, Washington, D.C., USA.

Liu, K., and M. L. Fearn. 1997. Lake sediment records of Hurricane Opal and prehistoric hurricanes from the Florida panhandle. Pages 397-398 in Preprints of the 22nd conference on hurricanes and tropical meteorology. American Meteorological Society, Boston, Massachusetts, USA.

Ludlum, D. M. 1963. Early American hurricanes 1492-1870. American Meteorological Society, Boston, Massachusetts, USA.

Metropolitan District Commission. 1995. Final management plan for the Quabbin Reservoir Reservation. Metropolitan District Commission, Boston, Massachusetts, USA.

Minsinger, W. E. 1988. The 1938 hurricane: an historical and pictorial summary. Blue Hill Meteorological Observatory, East Milton, Massachusetts, USA.

Minsinger, W. E., and C. T. Orloff. 1992. Hurricane Bob, August 16-August 20, 1991: a brief history. Blue Hill Meteorological Observatory, East Milton, Massachusetts, USA.

Minsinger, W. E., and C. T. Orloff. 1994. The Great Atlantic Hurricane, September 8-16, 1944: an historical and pictorial summary. Blue Hill Meteorological Observatory, East Milton, Massachusetts, USA.

National Oceanic and Atmospheric Administration. 1994. Global tropical/extratropical cyclone climatic atlas. CDROM, version. 1.0. NOAA/U.S. Navy, Washington, D.C., USA.

Neumann, C. J., B. R. Jarvinen, and A. C. Pike. 1987. Tropical cyclones of the North Atlantic ocean 1871-1986 Third revised edition. NOAA-National Climatic Data Center, Asheville, North Carolina, USA.

Neumann, C. J., and C. J. McAdie. 1997. The Atlantic tropical cyclone file: a critical need for a revision. Pages 401402 in Preprints of the 22nd conference on hurricanes and tropical meteorology. American Meteorological Society, Boston, Massachusetts, USA.

Perley, S. 1891. Historic storms of New England. Salem Press, Salem, Massachusetts, USA.

Powell, M. D. 1982. The transition of the Hurricane Frederic 
boundary-layer wind field from the open Gulf of Mexico to landfall. Monthly Weather Review 110:1912-1932.

Powell, M. D. 1987. Changes in the low-level kinematic and thermodynamic structure of Hurricane Alicia (1983) at landfall. Monthly Weather Review 115:75-99.

Powell, M. D., S. H. Houston, and T. A. Reinhold. 1994 Standardizing wind measurements for documentation of surface wind fields in Hurricane Andrew. Pages 52-69 in R. A. Cook and M. Soltani, editors. Hurricanes of 1992: lessons learned and implications for the future. American Society of Civil Engineers, New York, New York, USA.

Quine, C. P. 1995. Assessing the risk of wind damage to forests: practice and pitfalls. Pages 378-403 in M. P. Coutts and J. Grace, editors. Wind and trees. Cambridge University Press, Cambridge, UK.

Scatena, F. N., and M. C. Larsen. 1991. Physical aspects of Hurricane Hugo in Puerto Rico. Biotropica 23:317-323.

Simpson, R. H., and H. Riehl. 1981. The Hurricane and its impact. Louisiana State University Press, Baton Rouge, Louisiana, USA.

Smith, D. M. 1946. Storm damage in New England forests Thesis. Yale University, New Haven, Connecticut, USA.
Stephens, E. P. 1955. The historical-development method of determining forest trends. Dissertation. Harvard University, Cambridge, Massachusetts, USA.

Studholme, W. P. 1995. The experience of and management strategy adopted by the Selwyn Plantation Board, New Zealand. Pages 468-476 in M. P. Coutts and J. Grace, editors. Wind and trees. Cambridge University Press, Cambridge, UK.

Twisdale, L. A. 1978. Tornado data characterization and windspeed risk. Journal of the Structural Division, Proceedings of the American Society of Civil Engineers 104: $1611-1630$

Tyler, L. H. 1938. An album of pictures of the New England Hurricane and floods of September, nineteen hundred and thirty-eight. City Printing Company, New Haven, Connecticut, USA.

Westveld, M. 1956. Natural forest vegetation zones of New England. Journal of Forestry 54:332-338.

Willoughby, H. E. 1995. Mature structure and evolution. Pages 21-62 in Global perspectives on tropical cyclones. World Meteorological Organization, Geneva, Switzerland. 